by Brian L. N. Kennett ${ }^{1}$ and Richard S. Blewett ${ }^{2}$

\title{
Lithospheric Framework of Australia
}

\author{
${ }^{1}$ Research School of Earth Sciences, The Australian National University, Canberra, ACT 0200, Australia. E-mail: brian.kennett@anu.edu.au \\ ${ }^{2}$ Geoscience Australia, GPO Box 378, Canberra, ACT 2600, Australia. E-mail: richard.blewett@ga.gov.au
}

The Australian continent comprises an amalgamation of cratonic elements onto which there has been significant Phanerozoic accretion in the east. The result is a complex lithospheric structure with a broad span of ages of material at the surface. The continent is moving rapidly to the north at c. $7 \mathrm{~cm} / y$, relative to Asia. The collisions with the Eurasian and Pacific plates to the north, coupled to the interaction with the Pacific Plate along the eastern plate boundary through Tonga and New Zealand result in a complex pattern of stresses that is reflected in a moderate rate of intra-plate earthquakes. Extensive geophysical investigations at a continental scale have revealed details of the nature of the lithosphere. The lithosphere is thick (200 km or more) and seismically fast beneath the Precambrian domains of the centre and west of Australia and thins to the east, in a series of steps, to c. $80 \mathrm{~km}$ in the Tasman Sea. Large gravity anomalies in the centre of the continent attest to complex deformation in the Phanerozoic that has left a residue of domains with rapid changes in crustal thickness. The development of Australia's generally thick lithosphere has exerted fundamental control on the overall tectonic stability and consequent landscape evolution, the distribution of earthquakes and associated seismic risk, the evolution of sedimentary basins, as well as heat flow and other resource endowment.

\section{Introduction}

Classical plate tectonic theory has the outer layer of the solid Earth covered by rigid tectonic plates. Globally, there are 14 large and about 40 small tectonic plates, ranging in size from the Pacific Plate, which comprises $20.5 \%$ of Earth's surface, to the Manus Microplate, which comprises only $0.016 \%$ of the Earth's surface area (DeMetts et al., 2010). These tectonic plates are thought of as nearly rigid blocks of lithosphere, defined by their boundaries and their trajectory across the Earth's surface.

Australia, with an area of 7.69 million $\mathrm{km}^{2}$, is the Earth's largest island and smallest continent. The continental landmass, c. $3,700 \mathrm{~km}$ $\mathrm{N}-\mathrm{S}$ and 4,000 km E-W, occupies a significant part of the Australian Plate, which is currently separating from the Indian Plate in a diffuse zone in the Indian Ocean. Since its separation from Antarctica at c. $80 \mathrm{Ma}$, Australia has been moving steadily northwards, currently at c. $7 \mathrm{~cm} /$ year with respect to a hot spot frame of reference. Australia is the most rapidly moving continent on the globe, and has swept into the southern fringe of Asia with current collision active in Timor and Papua New Guinea (e.g., van Ufford and Cloos, 2005).

The lithosphere comprises two main components: the crust and the thicker lithospheric mantle. The nature of the surface is defined by its geological lineage and has a strong influence on local topography. Information at depth largely comes from geophysical investigations. Airborne magnetics provide strong control on the upper crust, whilst gravity observations are sensitive to deeper structure. Most information on the lower crust and the mantle lithosphere comes from seismological studies. Controlled source studies can provide detailed pictures of crustal structure and architecture, whilst passive seismic studies using distant earthquakes provide information on deeper structures. A relatively new approach exploiting the seismic noise-field is able to provide additional information on crustal structure.

Although the definition of the base of the lithosphere is a difficult problem, the global average continental lithosphere beneath shield areas is c. $200 \mathrm{~km}$ thick and beneath tectonically younger areas it is c. $80 \mathrm{~km}$ thick (Eaton et al., 2009). The global average crust is c. $40 \mathrm{~km}$ thick (Christensen and Mooney, 1995). Despite the average elevation of Australia being only $330 \mathrm{~m}$, the crust shows considerable variation in thickness with substantial areas thicker than $30 \mathrm{~km}$ and locally reaching $60 \mathrm{~km}$ thick in central Australia. The strong topography on the Moho compared with the surface elevation requires that isostatic compensation occurs at depth, with substantial density contrasts in the mantle lithosphere (e.g., Aitken, 2010).

The best controls on the thickness of the lithosphere come from seismological techniques, particularly surface wave tomography. The large cratonic areas of Australia show substantial portions with relatively thick lithosphere extending to $200 \mathrm{~km}$ or more in places. The transition to the shallow lithosphere in the E beneath the Paleozoic fold belts appears to take place in a sequence of discrete steps (Fishwick et al., 2008). The development of Australia's generally thick lithosphere has exerted fundamental control on the overall tectonic stability and consequent landscape evolution, the distribution of earthquakes and associated seismic risk, the evolution of sedimentary basins, as well as heat flow and other resource endowment.

Australia has preserved some of the oldest rocks and the oldest landscapes on the Earth. The continent is also covered by an extensive, but mostly thin, veneer of regolith. The preservation of these features in Australia is a function of the general landscape stability as well as the latitudinal position, which resulted in only minor glaciation during the last ice age. Beneath the regolith and sedimentary cover there lies an amalgam of Precambrian cratons and Paleozoic mobile belts. Understanding the way in which the continental fragments were assembled and the nature of the sutures between them requires the 
integration of geophysical and geological information on the nature of the whole lithosphere. As a result of major programs at the continental scale, Australia is well endowed with geophysical and geological datasets that allow penetration of not only the shallow cover, but also reveal the nature of the deeper parts of the lithosphere and down to the asthenosphere.

In this paper we provide a summary of the major continent-wide datasets that advance our knowledge of the deeper regions of Australia's lithosphere. With this aim, we make use of potential fields (gravity in particular), basins, radiometrics and heat flow, as well as a variety of both passive and active seismic techniques. We present maps of the main boundaries of the lithosphere, namely: (1) topography/bathymetry, (2) the depth to the Moho, and (3) depth to the asthenosphere. Figure 1 is a map of localities named in the text. Tectonic terms are defined in Table 1 of Huston et al. (2012).

\section{Physiographic setting of Australia}

Australia is an island continent with a landmass defined by a distinctive coastal outline, which has maintained its current shape for the last 6 kyr. At the time of maximum glaciation, the Australian mainland, Tasmania and the island of New Guinea formed a single larger and differently shaped landmass that stretched from the equator to latitude $45^{\circ} \mathrm{S}$. With the end of the Ice Age, global temperatures increased, much of the continental ice melted and sea level rose. This caused flooding of the land bridges between Tasmania and the Australian mainland 6 kya, and between Australia and New Guinea 8 kya. The rise in sea level inundated about one seventh of the larger ice-age continent isolating Tasmania, the Australian mainland and New Guinea.

In the absence of major mountain building episodes in the last $200 \mathrm{Myr}$, much of the present topography of Australia is the result of prolonged erosion by wind and water. Dating of the surface regolith indicates a weathering history stretching back over $300 \mathrm{Myr}$ in some parts of the continent (Pillans, 2008). The landscape was strongly shaped by continent-wide glaciation; large ice caps developed in the Permian when Australia was very near the South Pole, and this glacial influence on the landscape persists to the present day. By the early Cretaceous, Australia was already so topographically flat and of low elevation that a major rise in sea level divided the continent into three landmasses as a shallow sea spread over the land.

Today, the major physiographic features of the Australian continent comprise: (1) a major Western Plateau with localised ranges, (2) the Eastern Uplands with the highest land concentrated along the Great Divide and (3) an intervening zone of Interior Lowlands. The topography is subdued; the highest point on the continent, Mount Kosciuszko, is only 2,228 $\mathrm{m}$ above sea level, and the lowest point is Lake Eyre at $15 \mathrm{~m}$ below sea level. The average elevation is only 330 metres, the lowest of any of the continents (Figure 2).

Destructive plate margins are generally associated with mountain building, landscape rejuvenation and the formation of large reliable river systems. In contrast, the Australian continent has passive margins on three sides and the fourth is the lower plate of a collision zone in the N. Another important factor shaping Australian physiography is the fact that the continent was already at fairly low latitudes in the Pleistocene, so that glaciation was confined to small areas in SE Australia, with little reworking of the older landscape.

The continental slope on all margins is deeply incised, with steepsided canyons up to $2 \mathrm{~km}$ deep, reflecting either extinct drainage systems or the drowned valleys of current river systems (such as the canyon, to the west of Perth). On the southern part of the eastern margin the continental shelf is rather narrow, with a shelf break closer than $20 \mathrm{~km}$ from the coast and the base of the abyssal plain sometimes reaches within $60 \mathrm{~km}$ of the coastline (Figure 2). The conjugate southern margins of Australia along the Great Australian Bight and the Antarctic coast, created by the opening of the Southern Ocean, show somewhat wider continental shelves.

The broad continental shelf off Queensland, left behind after the Coral Sea opened, forms a foundation for the Earth's largest single living entity - the Great Barrier Reef (Figure 1) - with 2,900 reefs, 600 continental islands and 300 coral cays created in a mixed siliciclastic-carbonate depositional environment. The wide continental shelf between the coast of northern Australia and Indonesia, Timor and New Guinea represents the drowned remnants of the former single landmass. The extended continental shelf off Western Australia is host to most of Australia's natural gas resources, and is marked by complex embayments and salients left over from peri-Gondwanan fragments now forming basement in Southeast Asia being rifted in the Mesozoic (Huston et al., 2012).

\section{Tectonic setting of Australia}

The Australian Plate is undergoing a complex set of interactions with its neighbours. To the $\mathrm{S}$, an active spreading centre separates the Australian Plate from the Antarctic Plate. This margin developed with the break-up of Gondwana c. $99 \mathrm{Ma}$, with full separation by 35 Ma. Following a major plate reorganisation in the Pacific Ocean

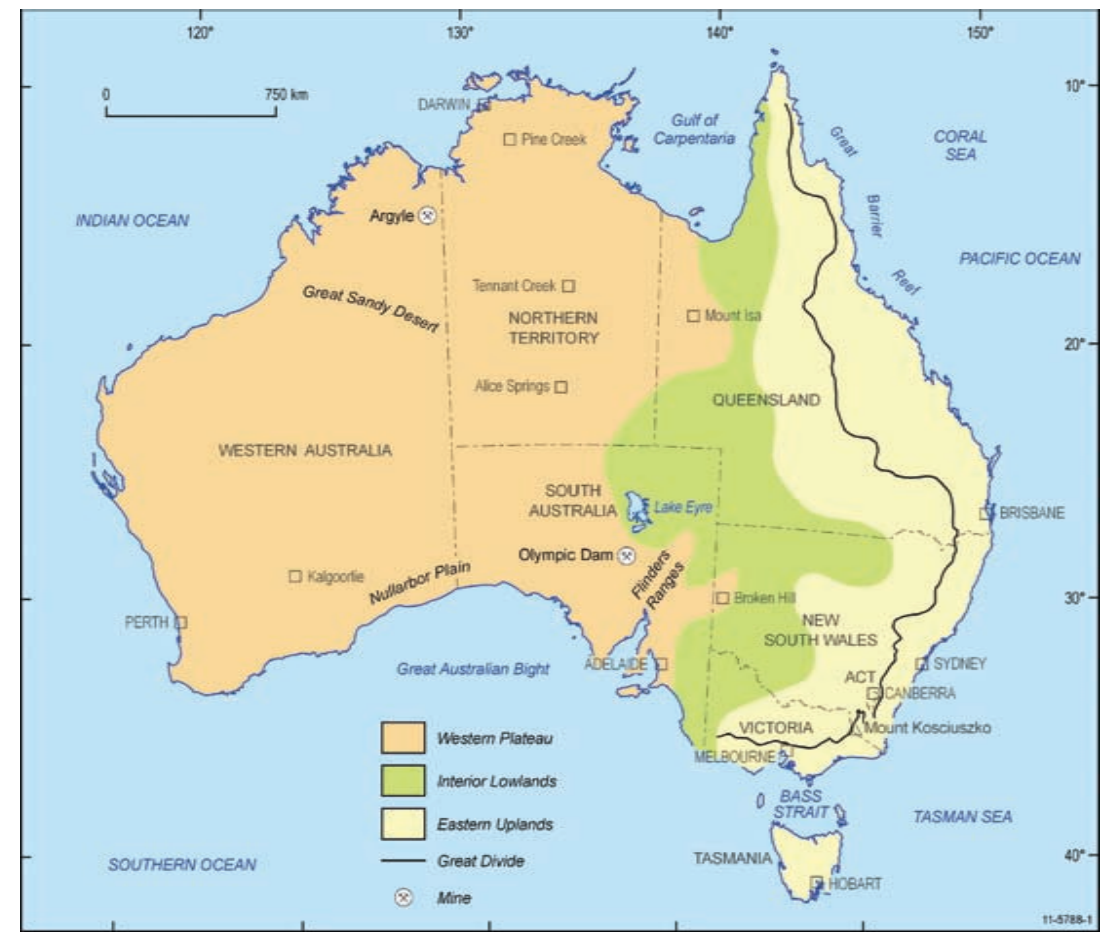

Figure 1 Map of localities and features mentioned in the text. 


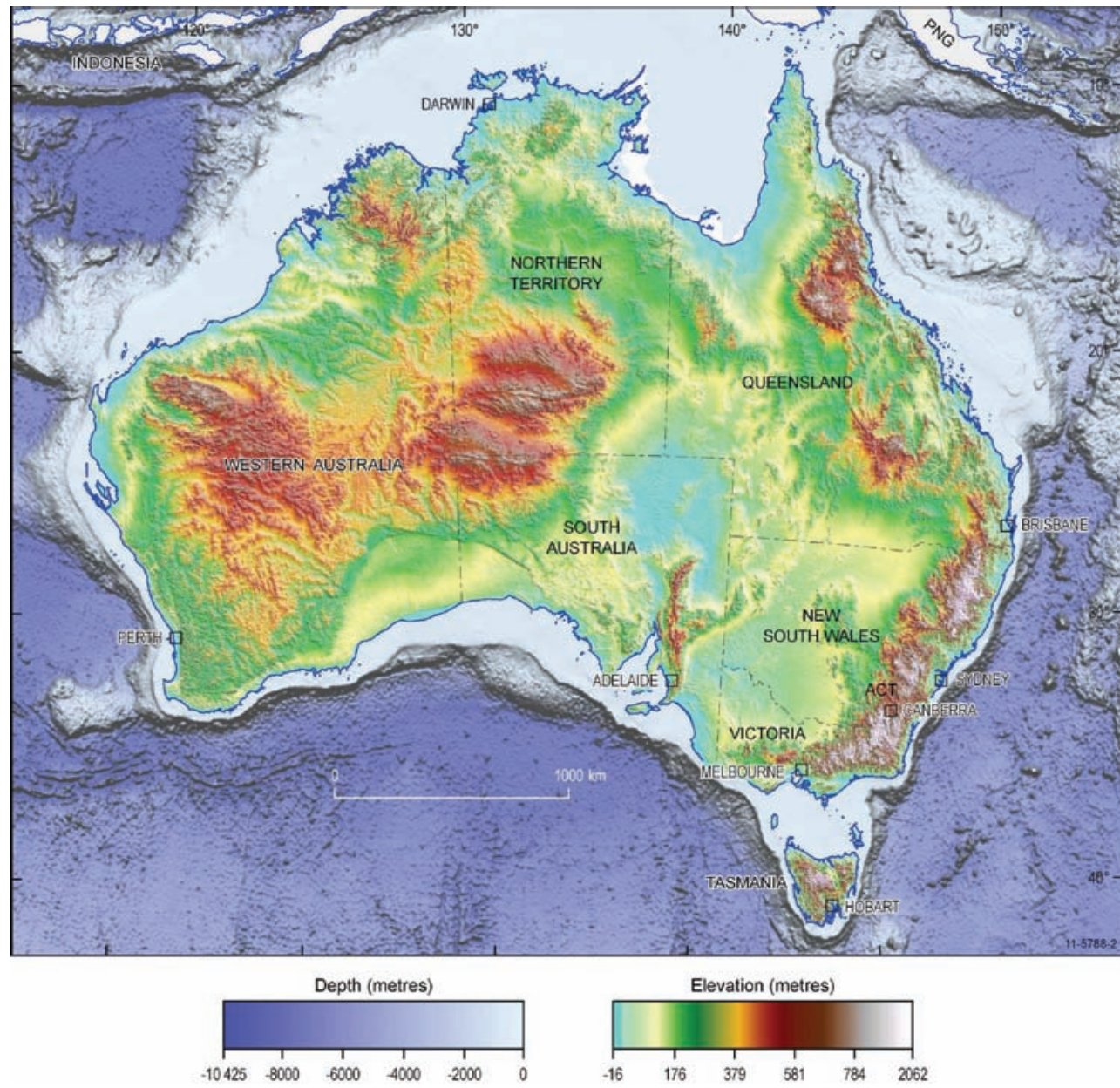

Figure 2 Topography and bathymetry of Australia (Source: Geoscience Australia). to the $\mathrm{W}$ the interaction is with the Eurasian Plate, with collision in the Banda Arc region and subduction of the Australian Plate beneath Indonesia at the Java and Sumatra Trenches (Figure 2). Subduction in the Banda Arc region may well already have come to a halt with the arrival of thick buoyant Australian lithosphere that cannot readily descend to depth. The western boundary of the plate is a diffuse zone called the Capricorn Plate, which lies between the Australian Plate and the Indian Plate further to the NW (De Metts et al., 2010).

The boundary forces acting upon the Australian Plate vary from tension in the $\mathrm{S}$ and $\mathrm{SW}$ to compression in the $\mathrm{E}$ and $\mathrm{N}$. The present stress state is largely controlled by compression originating from the three main collisional boundaries located in New Zealand, Indonesia and New Guinea, and the Himalaya (transmitted through the Indian and Capricorn plates). South of latitude $30^{\circ} \mathrm{S}$, the stress trajectories in the Australian continent are oriented E-W to NW-SE. North of $30^{\circ} \mathrm{S}$, the stress trajectories are closer to the present day plate motion, with an orientation between ENE-WSW and NE-SW (e.g., Hillis and Müller, 2003).

at c. $40 \mathrm{Ma}$, Australia acquired its present N-NE trajectory. Australia has migrated more than $3,000 \mathrm{~km}$ along this path at a rate of 6-7 $\mathrm{cm} / \mathrm{yr}$ over the past $45 \mathrm{Myr}$, making it the fastest moving continent since the Eocene (Tregoning, 2003).

Following breakup, Australia's initial drift was to the NW. But ridge subduction in the NW Pacific at c. 52 Ma resulted in termination of Tasman Sea spreading, and a change in the Australian Plate vector to its present-day northerly orientation. Sea floor spreading in the Southern Ocean accelerated at c. $45 \mathrm{Ma}$, and it was not until $35 \mathrm{Ma}$ that full separation of Australia and Antarctica occurred. Australia, as a separate continent, was released from the remnants of Gondwana and it commenced the northward march to meet Asia.

The eastern boundary of the Australian Plate with the Pacific Plate is marked by the Tonga-Kermadec Trench $\mathrm{N}$ of New Zealand where the Pacific Plate is being subducted, giving rise to many of the Earth's deep earthquakes. In New Zealand itself, there is oblique subduction along the E coast of the North Island with collision through the South Island moderated by the Alpine Fault. Beneath the Fiordland region of the South Island, the Australian Plate is subducting at the Puysegur Trench. This short subduction zone links to a largely strike-slip boundary passing Macquarie Island and linking to the boundaries of the Antarctic Plate (De Metts et al., 2010).

The Australian Plate is subducting beneath the Pacific Plate along its NE margin at the New Hebrides and Solomon Trenches. The northern boundary of the Australian Plate is complex. Continental Australia is colliding with the Pacific Plate through New Guinea, but
The complex pattern of stress in the continent is expressed in a relative high level of seismicity for what would normally be regarded as a 'stable' intraplate continental region. Recent seismic events with magnitude $>6$ are not uniformly distributed across Australia but clustered into regions towards the edges of major structural blocks (Figure 4). The rate of occurrence of earthquakes is normally low, but is punctuated by periods of enhanced seismic activity associated with one or more large earthquakes. Since 1901, seventeen earthquakes with magnitude $M>6$ have been recorded in Australia. The recurrence times for larger earthquakes, such as the 1988 Tennant Creek sequence with three $\mathrm{M}>6$ events in 12 hours, is more than 10 $\mathrm{kyr}$, so that the brief snapshot of seismicity available will certainly be incomplete. Many neotectonic features have been recognised through careful mapping across the continent (Clark et al., 2011). In the Flinders Ranges in South Australia there are clear indications of active faults thrusting Precambrian basement over Quaternary gravels (Quigley et al., 2010). The active intraplate deformation in Australia is likely to be guided by prior tectonic structures and thermal weakening of the lithosphere.

\section{Geological setting of Australia}

Rocks exposed at the surface in Australia span much of the Earth's geological history. The Archean regions include rocks older than 3700 Ma in Western Australia and 3100 Ma in the Gawler Craton of South Australia. The oldest zircon crystals yet found on the Earth, dating 


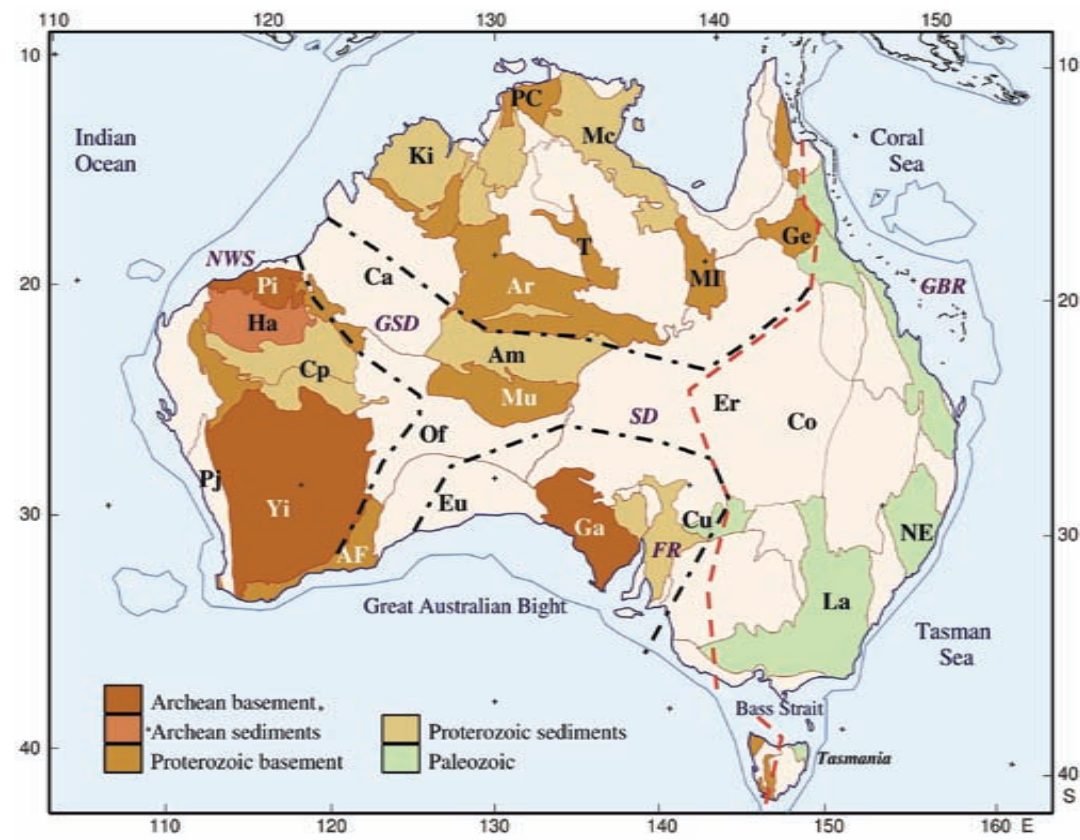

Figure 3 Simplified representation of the main tectonic features of Australia. The outlines of the major cratons are marked by chain-dotted lines. The approximate location of the boundary between Precambrian outcrop in western and central Australia and the Phanerozoic east (the "Tasman line") based on the reinterpretation by Direen and Crawford (2003) is indicated by a red dashed line. Key to marked features: AF - Albany-Fraser Orogen, Ar - Arunta Block, Am - Amadeus Basin, Ca - Canning Basin, Co-Cooper Basin, Cp - Capricorn Orogen, Cu - Curnamona Craton, Er - Eromanga Basin, Eu - Eucla Basin, Ga - Gawler Craton, Ge Georgetown Inlier, Ha - Hamersley Basin, Ki - Kimberley block, La - Lachlan Orogen, Mc - MacArthur Basin, MI - Mt Isa Inlier, Mu - Musgrave Orogen, NE New England Orogen, Of - Officer Basin, PC - Pine Creek Inlier, Pi - Pilbara Craton, Pj - Pinjarra Orogen, T - Tennant Creek Inlier, Yi - Yilgarn Craton; SD Simpson Desert, GSD - Great Sandy Desert, GBR - Great Barrier Reef, NWS North West Shelf.

back to $4400 \mathrm{Ma}$, occur in Proterozoic conglomerates within the Yilgarn Craton of Western Australia. In contrast, recent volcanic activity in both NE and SE Australia has left distinct volcanic edifices, with the latest eruptions in the SE dated at $4.6 \mathrm{ka}$.

Much of Australia is covered by extensive Mesozoic and younger sedimentary material (Figure 3 ). These cover rocks indicate the general tectonic stability of much of the continent from Mesozoic times to the Present. The underlying Australian continental crust was accreted in three major supercontinent cycles, each comprising about one third of the continental area from the Archean cratons in the W to Phanerozoic provinces in the E (Huston et al., 2012). Disparate Archean crustal elements were assembled into three major cratonic zones in the Proterozoic. The West Australian, the North Australian, and the South Australian elements were formed by c. $1830 \mathrm{Ma}$, and these cratonic elements were joined to the Rodinian supercontinent by 1300-1100 Ma. The fold belt structures of the Phanerozoic Tasman Element comprise the eastern third of Australia, which was accreted onto the eastern margin of the Precambrian cratons (e.g., Collins and Vernon, 1992). The break up of Gondwana, through a series of rifting events from c. $160 \mathrm{Ma}$, resulted in the formation of the passive margins around Australia, with the formation of the Coral and Tasman seas in the E, the Southern Ocean in the S and the Indian Ocean in the W (Huston et al., 2012). These rift events created the accommodation space for the Mesozoic sedimentary basins that host most of Australia's hydrocarbon resources.

There has been significant subsequent volcanism; in the Mesozoic, Australia was the continental margin of the subducting Pacific Plate and subsequently a chain of hot-spot related volcanism has developed through eastern Australia. The eastern margin of Australia has been influenced by sea-floor spreading in the Tasman Sea from c. $80 \mathrm{Ma}$ and back-arc spreading in the Coral Sea.

The eastern seaboard, including Tasmania, is a patchwork of Paleozoic metamorphic, sedimentary and igneous rocks. These rocks are revealed, as highlands, due to the rift-flank uplift generated by opening of the Tasman and Coral seas. The Flinders Ranges, a Yshaped region of uplifted Neoproterozoic sedimentary rocks in South Australia, attest to the influence of regional compression across the Australian Plate. Across northern Australia, large areas of mostly Proterozoic metasedimentary rocks occur in the Kimberly, Pine Creek, Macarthur and Mt Isa areas. These basins were filled with vast sandsheets during a time when the Earth's land surface was devoid of the stabilising influence of life, and became the containers for major base metal and uranium mineral systems.

\section{Penetrating the cover: the lithosphere of Australia}

\section{Potential Fields}

Much of the Australian continent is covered by a thick layer of regolith, which can exceed $100 \mathrm{~m}$ in many places. This regolith is a product of long term weathering largely unaffected by glacial action. In consequence, potential field geophysics is of major value in providing insight into buried rocks and structures beneath. As a result of the collective efforts of the state and territory geological surveys and Geoscience Australia, most of Australia has been covered with airborne magnetic surveys with high-quality data that provide valuable information on the upper part of the crust. Australia is covered by regional, $10 \mathrm{~km}$ spaced, gravity data, but many parts of the continent are sampled on a $1-2 \mathrm{~km}$ spaced grid.

The broad features of the structure of Australia appear clearly in the upward continuation of the gravity field across the continent (Figure 5). At an altitude of $25 \mathrm{~km}$ the small scale features linked to surficial structure are suppressed, and the major division of the continent can be seen. The western portion has pronounced negative gravity anomalies associated with the thick cratonic roots in the mantle with relatively low density so that they are buoyant. There is a N-S band of positive gravity anomalies near $140^{\circ} \mathrm{E}$, and a zone of weak positive anomalies towards the eastern seaboard. Even in the upward continued image there are considerable contrasts, and a group of alternating bands of E-W trending anomalies in central Australia with higher gravity values is prominent. These features dominate the surface gravity field and are associated with substantial localised changes in crustal thickness in the zone affected by the Devonian Alice Springs Orogeny and the c. 550 Ma Petermann Orogeny in 


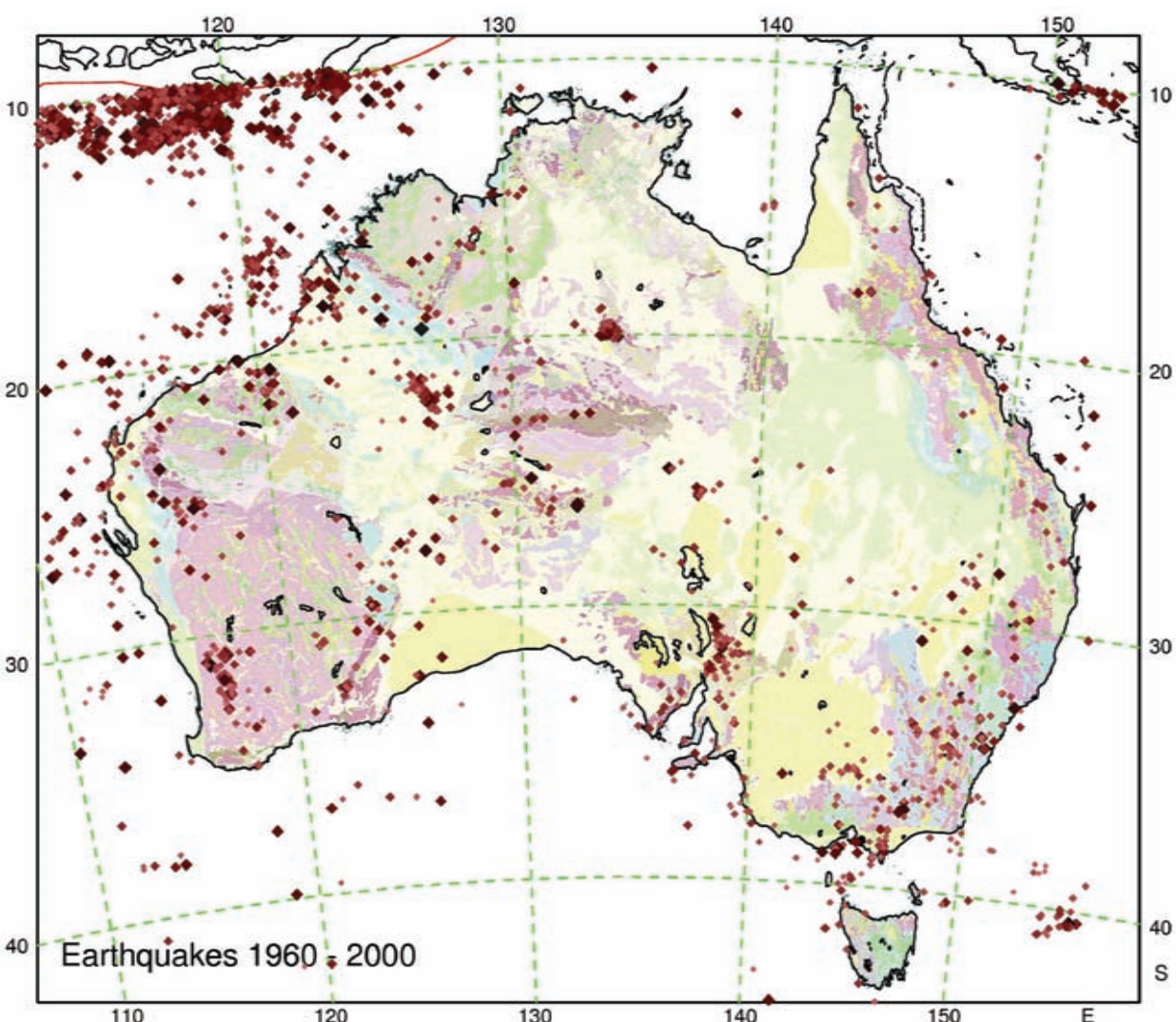

Figure 4 Earthquake locations for the period from 1960-2000 superimposed on a generalized geological map of Australia. The symbols increase in both size and depth of tone as the magnitude of the event increases.

the Musgrave Province. Similar bands of alternating N-S trending gravity anomalies in eastern Australia are associated with a series of island arcs and a succession of accretion events onto the evolving eastern margin of the continent. The major mineral province of $\mathrm{Mt}$ Isa has strong positive gravity anomalies which trend $\mathrm{N}-\mathrm{S}$, a tectonic grain imparted during the Meso-proterozoic. These gravity anomalies associated with Mt Isa are truncated in the S, with a sharp gravity gradient which formed during the latest Proterozoic breakup of the supercontinent Rodinia.

\section{Sedimentary basins}

Figure 6 displays the thickness of Neoproterozoic and Phanerozoic basins across Australia, building on input from reflection seismology, gravity and magnetic surveys. Although a significant part of Australia is covered in sediments, the sequences on the continent are generally less than $7 \mathrm{~km}$ thick (Figure 6). Deeper basins (>15 km) occur offshore particularly in NW Australia; they host most of Australia's oil and gas. Nevertheless the onshore basins are important with major coal deposits in eastern Australia, mostly from the Permian, and gas accumulations in the Cooper Basin in southern Queensland. The majority of these basins are associated with gentle downwarps associated with thermal sagging rather than localized rifting, and many in the western part of the continent lie on thick lithosphere.

\section{Radiometrics and Heat Flow}

A major effort has been made to assemble a continent-scale study combining the results of many different airborne radiometric surveys (Figure 7). The surveys measure the gamma-ray spectrum at a modest altitude (c. $100 \mathrm{~m}$ ) arising from the decay of the major radioactive elements potassium (K), uranium (U) and thorium (Th) in the top $30 \mathrm{~cm}$ of the ground. The energy distribution of the gamma-rays is specific to the decay chain for the particular elements and hence the relative contributions can be measured and extrapolated back to the concentrations of the radioactive elements at the Earth's surface. Corrections need to be made for the background radiation, the height of the aircraft above the ground, and the response and sensitivity of the detector. Further processing is required when many different surveys are combined to ensure that a common scale for element abundance is used across the entire image (Minty et al., 2009).

Figure 7 employs the normal mode of display of radiometric results using a three colour image with the $\mathrm{K}$ concentration on the red channel, Th on the green channel and $U$ on the blue channel. This ternary image can be regarded as a chemical map of the near surface distribution of the elements and is strongly correlated with the surface geology and the rate of erosion or deposition in the landscape. Areas low in all three radioactive elements appear as dark hues (ultramafics, quartzites and sandstones) and areas high in all three radioactive elements appear as white hues (felsic volcanics and granites). Weathering, erosional and depositional

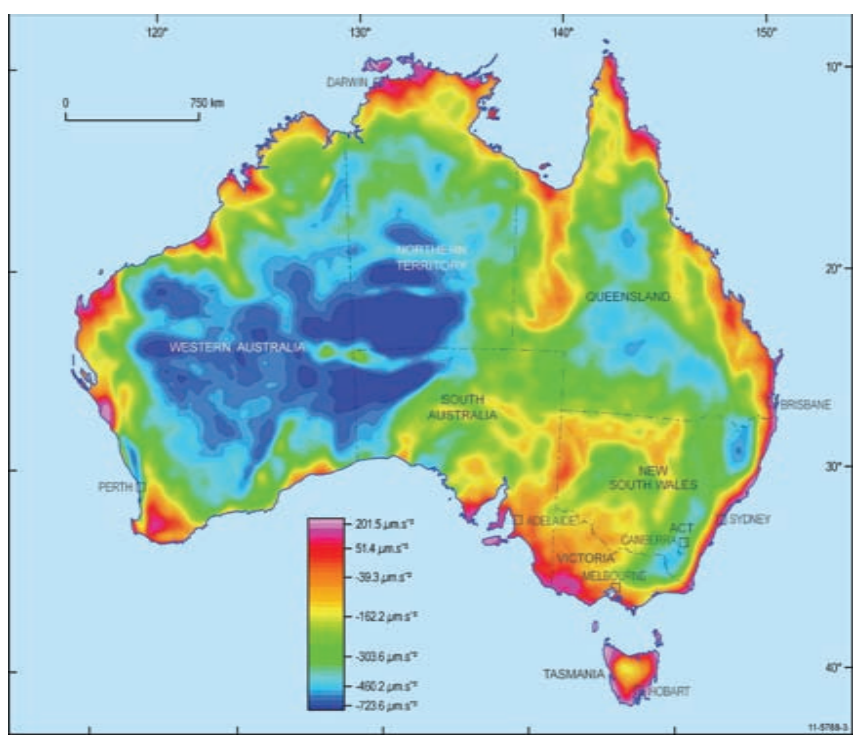

Figure 5 Gravity field upward continued to $25 \mathrm{~km}$, indicating the contrast between the ancient western core of the continent with negative gravity anomalies (blue) and the east with positive anomalies (yellow to red) (Source: Geoscience Australia). 


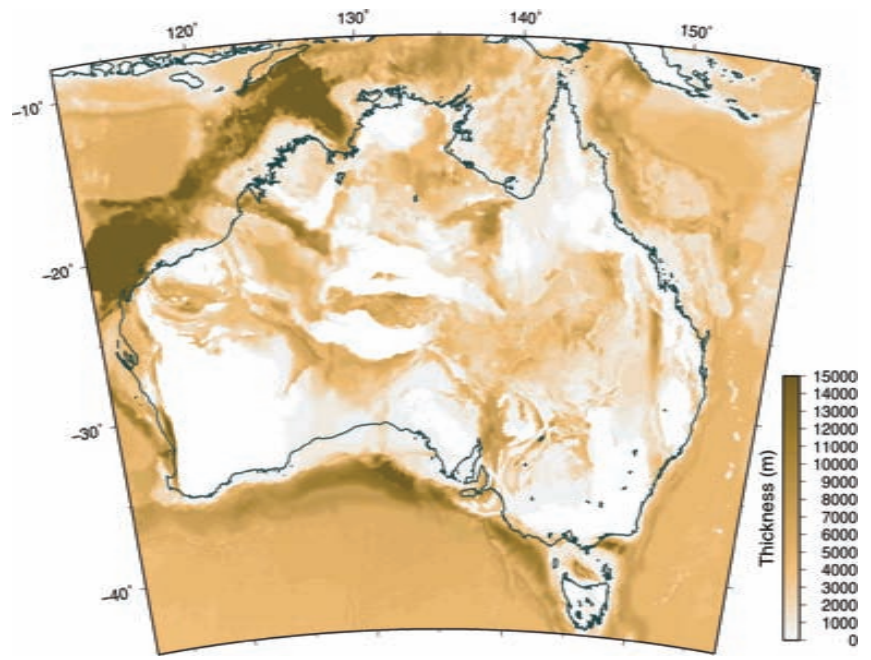

Figure 6 The distribution of sedimentary basin thickness across the continent based on the OZSeebase study (Frogtech, 2005).

processes play a large part in forming the radiometric response (Wilford, 2011). Many of the green and green-blue areas, representing high Th but low $\mathrm{K}$, are highly-weathered surfaces rich in Fe.

Localised high concentrations of the radioactive elements are clearly visible in the granites of the Pilbara Craton and the eastern Yilgarn Craton, in central Australia and in the New England region of northern New South Wales.

Many geological features and boundaries are well delineated in the continent scale image, e.g., the Mesozoic shoreline behind the Nullabor Plain with a clear distinction from the Th-rich Yilgarn Craton. The actively eroding fold-belts surrounding the Kimberley region are prominent against the more sombre tones of the Kimberley itself. There is also a clear image of the remote Canning Basin in Western Australia, much of it forming the Great Sandy Desert between the Kimberley and the Pilbara regions. The mineral provinces around Mt Isa and Broken Hill have a distinctive signature. Other concentrations occur in the Flinders Ranges, which is also noted as a zone with enhanced geothermal heat flux, most likely associated with a high concentration of these heat-producing elements in the crust. The granites of the Tasman Element along the eastern margin are bright red and white colours and shades, consistent with their high concentrations in radioelements (Figure 7).

The high concentrations of the radioactive elements in the crust in many parts of Australia leads to high temperatures at depth, particularly where radioactive granites are blanketed with sediments, as in the NE parts of South Australia. Sampling of heat-flow across the continent is rather patchy, but is sufficient for the general pattern of temperature distribution to be determined (Figure 8). There is undoubtedly considerable potential for the exploitation of geothermal energy resources, but many of the best prospects lie far from the major population centres where the energy is needed (Kirby and Gerner, 2010; Jones et al., 2011; Webber et al., 2011).

\section{Seismological studies of the lithosphere}

Australia has made extensive use of seismological methods in the study of the crust and upper mantle using both man-made and natural sources (Figure 9). A number of major refraction experiments were carried out from the 1960s into the 1980s and provide an important control on seismic wavespeeds across the continent. There has been little such work since, except some off-shore/on-shore experiments mostly in Western Australia. Reflection studies of the whole crust have grown from short experimental spreads in the 1960s to large-scale transects. A historical overview and extensive bibliography of the full range of active seismic experiments up to 2006 is given by Finlayson (2010).

A nearly $2000 \mathrm{~km}$ long reflection transect with 20 second recording was built up across southern Queensland in the 1980s using explosive sources. Explosive sources continued to be used until 1997, when they were replaced with arrays of powerful vibrator sources. Since 2004 there has been a major national investment in seismic reflection work funded through investment from Geoscience Australia, state and territory geological surveys and, since 2007, the AuScope

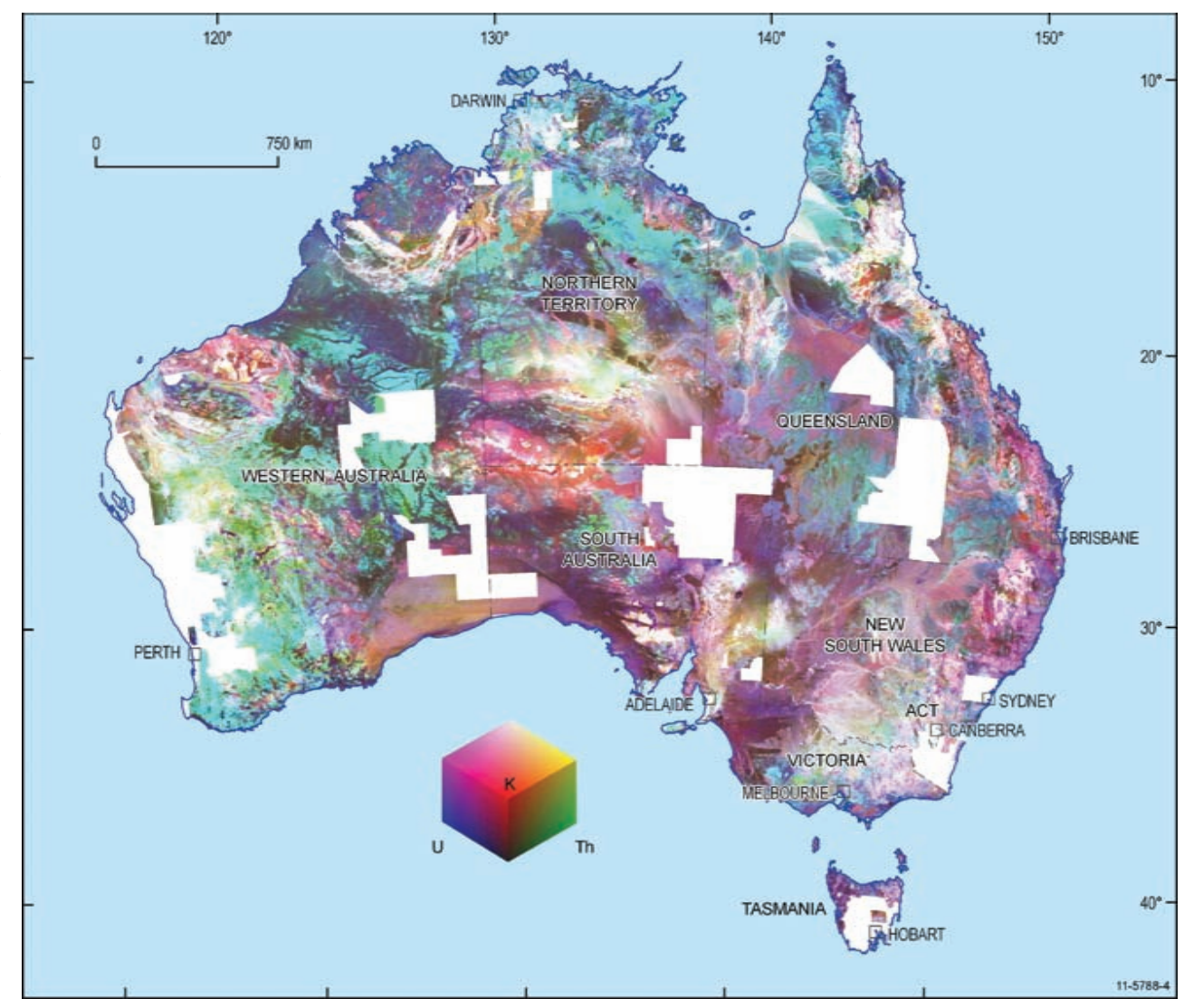

Figure 7 Gamma-ray spectrometric map for the continent of Australia $-K$ (red), Th (green) and $U$ (blue) (after Minty et al., 2009). The pale grey areas are data acquisition gaps (Source: Geoscience Australia). 


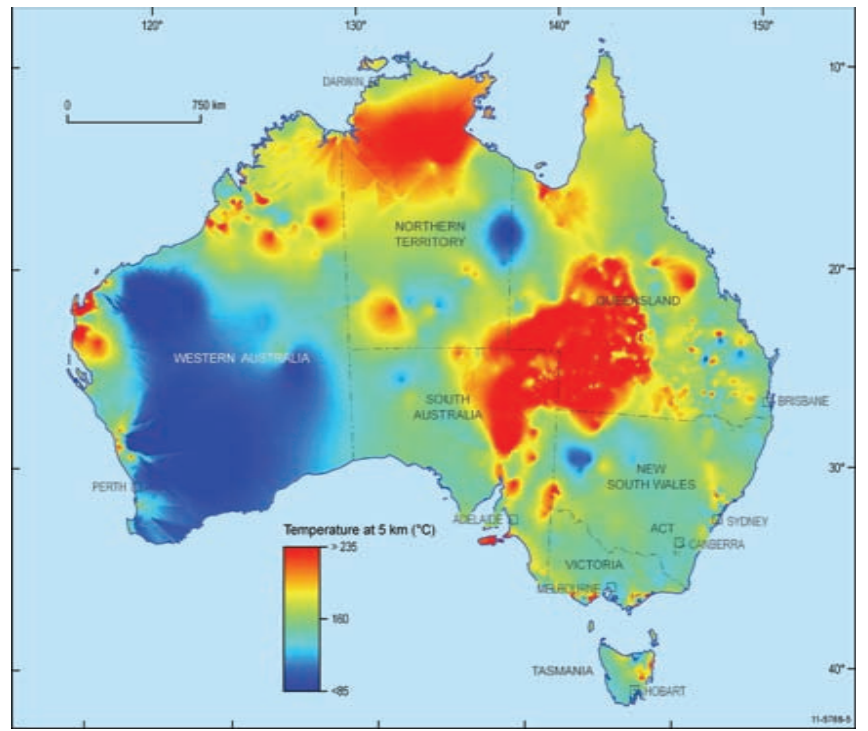

Figure 8 Distribution of temperature at $5 \mathrm{~km}$ across the Australian continent estimated from heat flow studies (Source data: Earth Energy Pty Ltd; AUSTHERM database; Geoscience Australia).

infrastructure initiative. Over $10,000 \mathrm{~km}$ of full crustal reflection profiles have been acquired with recording to 20 seconds or more. This very large effort has provided new insights into crustal structure, architecture and evolution in a number of parts of the continent. The dense sampling provided by the reflection transects has been of considerable value in mapping the character and geometry of the Moho across the continent.

The configuration of earthquake belts around the margins of Australia provides a wealth of events at suitable distances to be used as probes into the seismic structure of the upper mantle. Until recently there have only been a few permanent high-fidelity seismic stations on the continent. Much data collection has therefore been acquired through extensive deployments of portable broadband stations for periods of a few months at each site. This approach was pioneered with the SKIPPY experiment (van der Hilst et al., 1994) where a group of stations were progressively moved across the continent in a sequence of deployments. This style of experiments has inspired many similar efforts world-wide (such as major deployments in South Africa, James et al., 2001, and the US Array, http://www.usarray.org).

The combination of a long duration of recording at the permanent stations and the broad spatial coverage of the portable stations provides an excellent resource for studies of the lithosphere. A wide range of techniques, which exploit different aspects of seismograms, can be used to gain information on the 3-D structure in the crust and mantle.

A sequence of dense deployments of 3component shorter-period instruments across the SE corner of the continent since 1999 has been brought together in the WOMBAT project (Rawlinson et al., 2011). These dense deployments provide detailed information on crustal and mantle structure.

\section{Passive seismic}

A wide range of techniques have been employed to exploit the wealth of information available from the extensive coverage of the continent using portable seismic instruments. Most of the studies exploit seismograms from earthquakes, either in the regional belts of events to the $\mathrm{N}$ and $\mathrm{E}$ of Australia, or from more distant sources. A new technique, which is of particular value for crustal studies, exploits the ambient noise field, by working with the stacked correlation of records at pairs of stations. The result is equivalent to having a virtual source at one of the stations with a receiver at the other. The surface wave energy is the most prominent feature of the stacked correlation and has been exploited by Saygin and Kennett (2010) to map the upper and middle crust.

Large amplitude surface waves can be used in a tomographic inversion to determine the 3-D variations in shear wavespeed in the mantle. These relatively late arrivals in the seismogram travel nearly horizontally from regional events (e.g., Debayle and Kennett, 2000; Fishwick et al., 2005). This approach to surface-wave tomography relies on matching the waveforms on individual paths and then mapping of the path-specific constraints on shear structure into a 3-D model. In contrast, the higher frequency body wave arrivals are refracted back from the variations in structure in the mantle and are particularly sensitive to discontinuities in structure. Observations out to a distance of $3,000 \mathrm{~km}$ provide coverage of the structures down through the lithosphere-asthenosphere boundary to the upper mantle transition zone below northern Australia. The combination of shortperiod and broadband observations has provided detailed information on both $\mathrm{P}$ and $\mathrm{S}$ wavespeeds and the variation in seismic wave attenuation with depth. Further information on 3-D variations in structure can be extracted from the patterns of travel-time residuals. The combination of these different types of information allows the main features of upper mantle structure to be characterised. There is

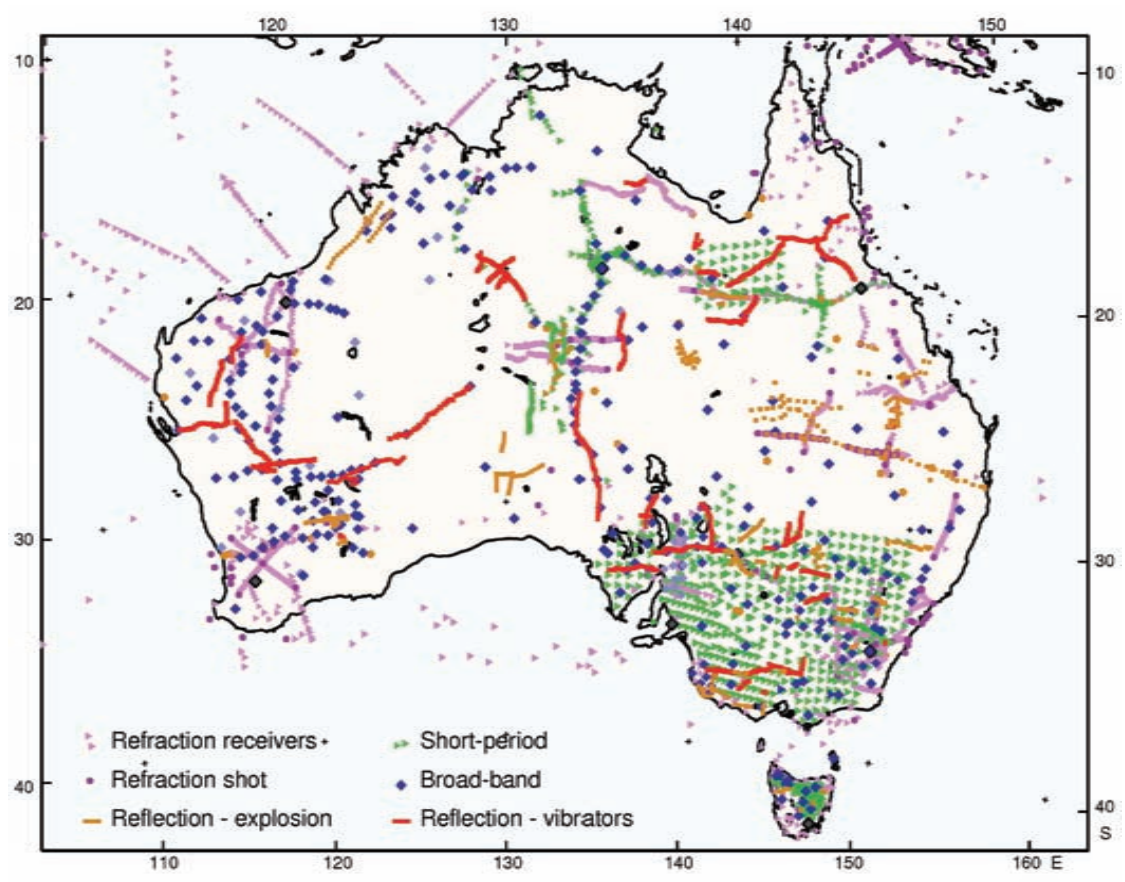

Figure 9 Locations of seismological studies across Australia showing the locations of active studies: refraction surveys (purple) and shotpoints (circles), reflection lines (orange - explosive sources, red - vibrator sources) and passive studies: broad-band recording stations (diamonds) and short-period stations (triangles), as indicated on the key. 
a dramatic increase in seismic wave attenuation in the asthenosphere and thus such observations are important for mapping out the base of the lithosphere.

\section{Receiver functions}

Extensive use has been made of receiver function studies that exploit the conversions and reverberations that follow the onset of the seismic signal. These studies provide important information on crustal and uppermost mantle structure, particularly the depth and nature of discontinuities. The receiver function is constructed from the beginning of a seismogram by extracting the influence of the source; the resulting information on structure near the receiver can then be elucidated with careful modelling.

The receiver function studies provide an important supplement to the limited sampling available from refraction experiments and provide a full continental coverage. Initial work in eastern Australia by Shibutani et al. (1996) was extended by Clitheroe et al. (2000) to cover most of the continent, using portable broad-band stations and the limited number of high-quality permanent stations at the time. A set of receiver function studies have been made of the West Australian cratons as detailed coverage has become available through portable broad-band deployments (Reading et al., 2007).

Despite higher noise levels and more limited bandwidth, valuable receiver function controls on crustal thickness can be extracted from teleseismic records at higher frequencies. For example, stacking and waveform fitting, coupled to local surface-wave dispersion results, has been used to improve the spatial coverage of Moho depths in SE Australia.

\section{Body-wave tomography}

The initial application of mapping of the relative delay times of seismic arrivals was to investigate the major gravity anomalies in central Australia (Figure 5) by using linear profiles of portable instruments (Lambeck et al., 1988). These studies revealed the need for substantial, but localised, variations in crustal thickness, to satisfactorily model the seismic results. The crustal thickness variations have since been corroborated by deep seismic reflection profiling across the Arunta Block and, more recently, across the Musgrave Province (Korsch and Kositcin, 2010a).

The arrival times of seismic phases at the various broad-band stations from regional earthquakes have been picked and used in a number of studies (e.g., Kennett and Abdulah, 2011). The distribution of earthquakes means that detailed resolution using seismic waves refracted back from the mantle is confined to the northern part of Australia. Nevertheless these results provide independent corroboration of the presence of fast seismic wavespeed structure extending to $220 \mathrm{~km}$ or more beneath the cratons of central and western Australia.

High resolution work has been carried out in SE Australia using the dense networks of short-period stations that can be very clearly seen in Figure 9. Rawlinson et al. (2010) have combined refraction results from a marine survey around the island of Tasmania recorded at land stations with teleseismic data recorded at dense seismic arrays on the island. They have developed a high resolution $\mathrm{P}$-wave tomographic model including a description of the crust-mantle boundary, which is consistent with the limited results from deep reflection studies in Tasmania (e.g., Drummond et al., 2000).

Tomographic inversions using data from distant earthquakes were originally conducted for the individual deployments using the relative arrival times of seismic phases. This approach minimised the mapping of structure from outside the zone for which the inversion is being undertaken. The WOMBAT project (Rawlinson et al., 2011) brings together the results from all the different deployments so that much more comprehensive imaging can be undertaken (Figure 10), revealing considerable structure in the crust and upper mantle. Across such a large region there can be considerable gradients in background structure that are too long wavelength to be imaged by the various deployments. Fortunately, by using information from surface wave tomography, a base model can be constructed from the large scale features in seismic wavespeed. Into this image, more detailed inversions of the arrival times can be incorporated, adding finer scale features to the base model. The results from this combined approach are providing new constraints on the base of the lithosphere in SE Australia.

\section{Thickness of crust}

A new model for the depth to the Moho has recently been developed by using the entire suite of available data from refraction, reflection and receiver function studies (Kennett et al., 2011). The coverage is now very good across most of the continent (Figure 11), but there are still a number of remote desert areas with difficult access where sampling is rather sparse.

The inclusion of Moho picks at $20-40 \mathrm{~km}$ intervals taken from more than $10,000 \mathrm{~km}$ of reflection profiling has been particularly important in constraining the Moho map. Previously isolated seismic

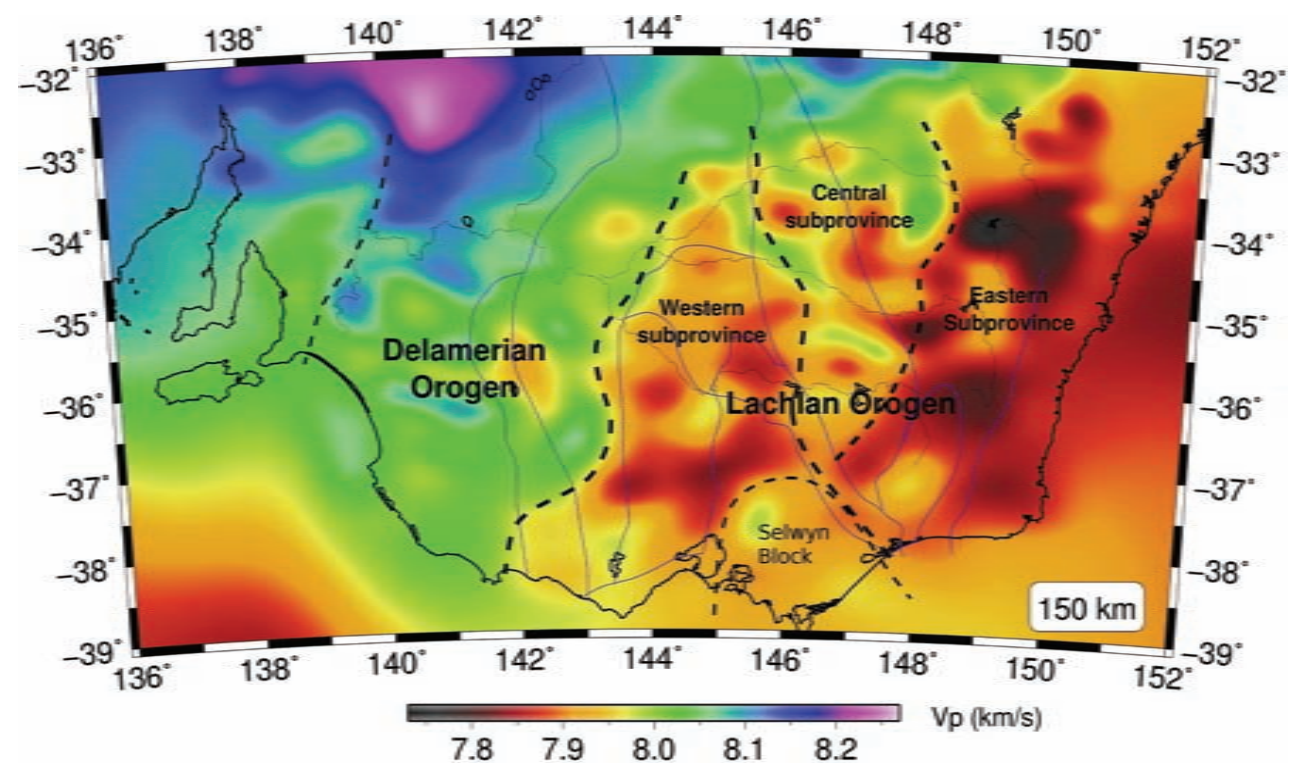

Figure 10 Seismic tomography for the SE Australian region using data from the WOMBAT array (Rawlinson et al., 2011). The P wavespeed is displayed at a depth of $150 \mathrm{~km}$. 


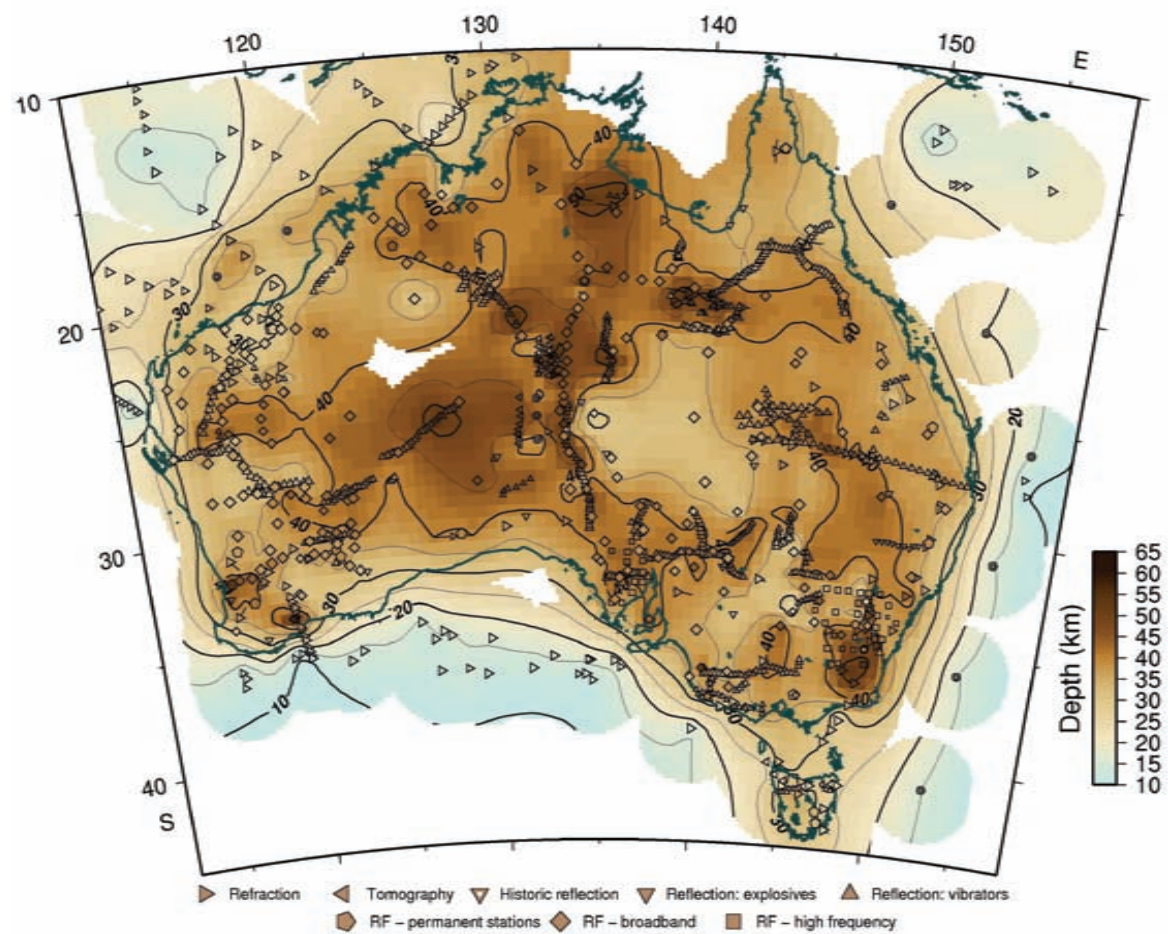

Figure 11 The depth to the Moho across Australia derived from a combination of seismic refraction, refraction and receiver function studies (Kennett et al., 2011). The values obtained from different classes of observations are indicated by the colours attached to the distinctive symbols for each data type.

stations can now be linked, and also cross-checks provided on results from other methods. In general, the consistency between techniques is very high and in most places the variation in crustal thickness estimates are less than $3 \mathrm{~km}$. The thickest crust (more than $50 \mathrm{~km}$ thick) is mapped beneath the eastern highlands, central Australia and the Mt Isa region. The crust thins towards the continental edge, although it is still over $35 \mathrm{~km}$ thick in regions of the North West Shelf (Figure 11). The thinnest crust on the mainland is c. $30 \mathrm{~km}$ or less in the NE part of South Australia; a region with coincident high heatflow anomalies (Figure 8).

There is significant variation in the seismic character of the crustmantle transition. The character varies from a very distinctive and sharp change in reflectivity that may extend laterally for 100 s of kilometres, to a more diffuse and difficult to identify boundary. A sharp Moho is particularly characteristic of the main cratonic regions of Archean crust such as the Yilgarn Craton (Goleby et al., 2002), but also the Proterozoic (in the upper crust) regions of NE Queensland (Chopping and Henson, 2009). The more diffuse character Moho occurs in Proterozoic crustal blocks, such as the Curnamona and eastern Gawler cratons (Korsch and Kositcin, 2010b), or northern Gawler Craton to Arunta Block in central Australia (Korsch and Kositcin, 2010a).

The reflection profiling results provide evidence for a number of sharp changes in crustal thickness, notably in central Australia (e.g., Goleby et al., 1989; Clitheroe et al., 2000) where offsets may exceed $20 \mathrm{~km}$. The rate of change of crustal thickness can be rapid, with also small jumps apparently related to crustal sutures as in northern Queensland (Chopping and Henson, 2009). Such features pose a challenge when we try to provide a suitable representation of the Moho surface (Figure 11).

\section{The lithospheric mantle}

The seismological results reveal a complex pattern of 3-D structure beneath the Australian Plate. The dominant control on the seismic wavespeeds in the mantle is from temperature, with a decrease in velocity with increasing temperature. As a result the variations in the wavespeed with depth can be interpreted in terms of changes in lithospheric thickness. The cratonic region in the centre and $\mathrm{W}$ of Australia is underlain by a thick mantle lithosphere extending to over $200 \mathrm{~km}$ depth with fast wavespeeds (especially for shear waves). Beneath the Tasman Element in the E, a region of younger Phanerozoic upper crust, the lithosphere is generally thinner (less than 140 $\mathrm{km})$ and the asthenosphere has a pronounced low velocity zone for shear waves with high attenuation of shear wave energy.

The configuration of regional earthquakes around Australia has been extensively exploited in the analysis of multiply reflected shear waves and surface waves that form the most prominent part of seismograms. A variety of styles of seismic tomography have been employed to build 3-D maps of the shear wavespeed distribution beneath the whole continent (e.g., Debayle and Kennett, 2000; Simons et al., 2002; Fishwick et al., 2005; Yoshizawa and Kennett, 2004; Fichtner et al., 2009, 2010). As a result, structural variations have been imaged on horizontal scales down to $250 \mathrm{~km}$, and significant substructure is apparent within the zones of both elevated and lowered wavespeeds (Figure 12). The centre of Australia has relatively low wavespeeds at $75 \mathrm{~km}$, but there are strong gradients with depth and by $125 \mathrm{~km}$ a broad zone of fast wavespeeds is established across the centre and $\mathrm{W}$ of Australia that persists to more than $200 \mathrm{~km}$ depth. In contrast, in the Tasman Element, the seismic wavespeeds in the mantle are somewhat lower and the lithosphere is relatively thin, with estimates c. $80 \mathrm{~km}$. The Tasman Sea region displays quite low shear wavespeeds (down to $4.2 \mathrm{~km} / \mathrm{s}$ ), probably as a result of residual heat left from failed rifting c. $80 \mathrm{Ma}$. Fishwick et al. (2008) have presented evidence for the progressive eastward thinning of the lithosphere across Australia, which occurs as a series of discrete steps with quite sharp transitions. This result poses interesting questions as to how the lithospheric steps can be maintained over extended periods of geological time.

Goes et al. (2005) used the patterns of seismic wavespeeds determined from surface-wave tomography to extract information on the temperature in the mantle lithosphere beneath Australia. The mantle lithospheric temperature range is c. $1,000^{\circ} \mathrm{C}$, with a broadscale correlation between temperature and tectonic age. Within each tectonic province there are, however, temperature differences ranging from $200-700^{\circ} \mathrm{C}$. There are no significant differences in the temperatures beneath the Archean and Proterozoic regions. In the E, the temperatures approach the moist solidus.

\section{Anisotropy}

The path of seismic waves is partly controlled by mantle 


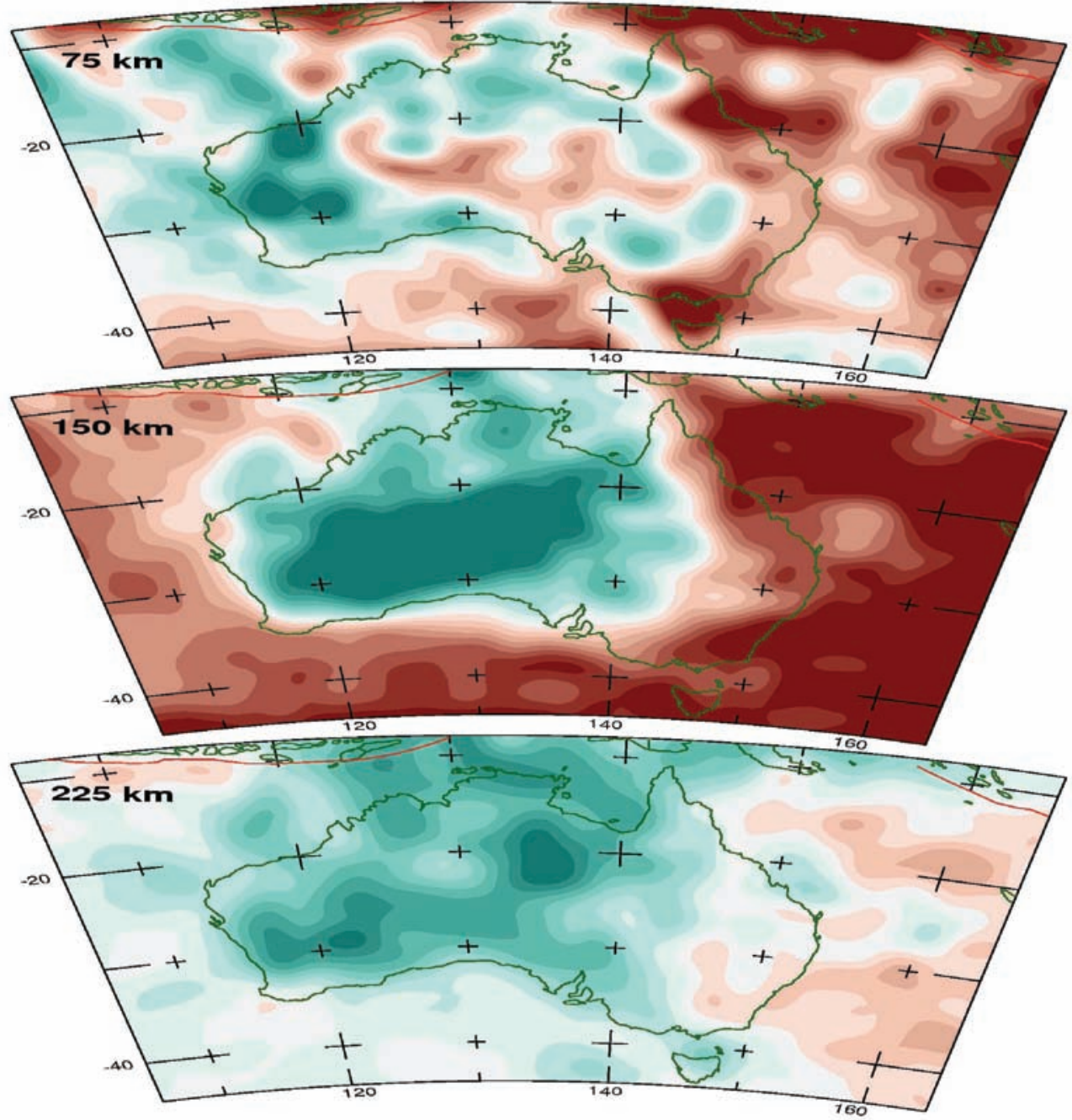

SFvel06 Wavespeed $[\mathrm{km} / \mathrm{s}]$ 4.20

Figure 12 Map views at depths of $75 \mathrm{~km}, 150 \mathrm{~km}$ and $225 \mathrm{~km}$ for the 3-D shear wavespeed distribution below the Australian region, based on the model of Fishwick et al. (2008).

mineralogy and structure. Olivine, the dominant mantle mineral, responds to stress by aligning its crystallographic structure. It is this structural alignment that influences the transmission of seismic waves. The seismic wavespeeds vary along the crystallographic axes so that waves travelling in different directions have different effective wavespeeds. The effects are most noticeable for shear waves and lead to different travel times for waves with orthogonal polarisation. The difference in propagation time, "shear wave splitting", provides a measure of the strength of anisotropy and hence crystal alignment.

Observations of splitting in the times of arrivals of refracted shear waves on the radial and tangential components of waves returned from the upper mantle were used by Tong et al. (1994) to show the presence of anisotropy in the lithosphere. Subsequently, Heintz and Kennett (2005) made an analysis of shear wave splitting for the core refracted (SKS) waves for stations across the continent using all available stations. The advantage of using such waves is that they are repolarised on exit from the Earth's core so that any shear wave splitting has to be imposed on the wave by its passage through the mantle on the receiver side. There is a weak correlation of splitting with geological features, but many stations show very little splitting 4.71

of the SKS waves in Australia (Heinz and Kennett, 2005). An alternative approach to anisotropy studies is provided by the analysis of surface waves. Debayle et al. (2005) show that Australia is distinctive among the continents by displaying a twist in the direction of fast propagation of Rayleigh waves from E-W at $100 \mathrm{~km}$ depth to near alignment with the absolute plate motion at $200 \mathrm{~km}$ depth within the zone of fast seismic wavespeeds. It is therefore likely that the complex patterns of behaviour are induced by the superimposition of effects from multiple anisotropic layers (Fouch and Rondenay, 2006).

\section{Transition to the} Asthenosphere

The lithosphere beneath the older parts of the continent can be readily recognised by fast shear wavespeeds (up to $4.7 \mathrm{~km} / \mathrm{s}$ ), but the transition to the asthenosphere is not marked by any sharp transition. Rather there is a gradation from a conductive to a convective regime, most likely linked also to a change in rheology from dislocation to diffusion creep. The presence of the asthenosphere is manifest in enhanced seismic attenuation. The fast lithospheric wavespeeds are accompanied by little loss of seismic energy, enabling high frequency waves to propagate readily from subduction zones into continental Australia (Kennett and Furumura, 2008). These high frequency waves are, however, suddenly lost when the seismic waves penetrate into the asthenosphere, because of its much higher attenuation of shear waves than in the lithosphere (Gudmundsson et al., 1994). Kennett and Abdulah (2011) have used the full range of arrivals at portable stations across Australia to undertake attenuation tomography that confirms the presence of much stronger attenuation below $210 \mathrm{~km}$ depth.

Figure 13 shows an estimate of the depth to the base of the lithosphere based on a variety of lines of evidence including the analysis of refracted waves in the mantle, the wavespeeds and gradients deduced from surface-wave tomography and body-wave tomography. The contrast between thick lithosphere in the centre and $\mathrm{W}$ and thinner lithosphere in the $\mathrm{E}$ is very clear and the nature of the transition is consistent with the analysis of Fishwick et al. (2008). The base of the lithosphere is somewhat irregular and this is likely to impose complex stress patterns from the relative motions of the thick continental lithosphere and the free-flowing asthenosphere. Farrington et al. (2010) have suggested that a southern edge to the cratonic lithosphere has produced edge induced convective flow associated with the northern motion of Australia at c. $7 \mathrm{~cm} / \mathrm{yr}$ that is 


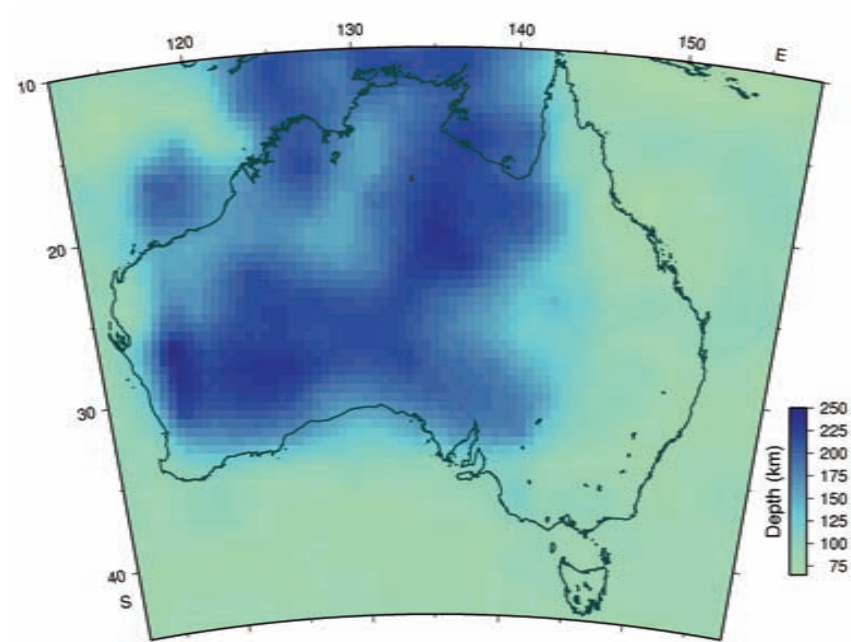

Figure 13 Estimate of the depth to the base of the lithosphere beneath Australia derived from a variety of seismological data.

linked to the eruption of basalts of the Newer Volcanic Group in Victoria and South Australia, with the youngest event dated at $4.6 \mathrm{ka}$.

\section{Magnetotelluric Surveys}

In recent years there has been considerable investment in magnetotelluric studies across Australia. Major reflection profiles in Queensland, central Australia and Western Australia have been accompanied by magnetotelluric soundings, with instrument spacing of c. $10 \mathrm{~km}$. Earlier studies using a limited number of instruments have provided insights into crustal lithospheric structure in southern Australia, notably near the major mines at Olympic Dam (Heinson et al., 2006), at Kalgoorlie (Blewett et al., 2010) and across the thrusts belts in central Australia (Selway et al., 2006). Whereas seismic properties depend on the physical state of the material, the electrical conductivity varies over a much larger rather with a strong influence from local chemistry, e.g. the presence of fluids or graphite.

\section{Discussion}

In this summary article we are only able to touch on some of the wide range of studies that have been made of the Australian lithosphere. Many other aspects of lithospheric structure and properties are presented in a set of compilations by Drummond (1991), Braun et al. (1998) and Hillis and Müller (2003).

The processes and timing of lithosphere formation are controversial (Eaton et al., 2009). Old and cold cratonic lithosphere is strong and buoyant, and therefore difficult to destroy and recycle (Lee et al., 2011). Much of Australia is underlain by a thick lithosphere that has undoubtedly influenced the tectonics, topography, seismicity, basin evolution and ultimately the landscape. The deeper lithosphere beneath Australia is imaged well by seismic tomography (Figures 12 and 13). At a deeper level, there are major differences in the thickness of the continental lithosphere between the eastern third of the continent $\left(\mathrm{E}\right.$ of $\left.140^{\circ} \mathrm{E}\right)$ and the western two thirds (Figure 13). The thicker western part of the continent occurs below the known region of Precambrian crust. The thinner eastern part occurs below the mainly Phanerozoic Tasman Element (Figure 3). The lithospheric differences of over $100 \mathrm{~km}$ in thickness have a material effect on the way the plate bends under load. Such flexures have predictable consequences and go some way to explain the topographic differences (Stüwe, 1991).

Despite the average flatness of Australia, there are notable differences between the $\mathrm{E}$ coast and its hinterland and the rest of the continent (Figure 2). The highest mountains in Australia (up to 2,228 $\mathrm{m}$ ) occur in the SE, and they are part of a 3,500 km long chain of elevated topography mirroring the geometry of the coast. Although the southern and western coastal hinterlands have similar passive margin tectonic settings with ocean crust of similar age (Müller et al., 1997), they do not show the elevated topography of the E (Figure 2). These topographic differences have influenced the climate and the available topographic head for river networks to form, which in turn influence uplift and erosion rates.

The northward movement of the continent, which started at c. $80 \mathrm{Ma}$, has brought Australia in the more recent times into collision along the northern plate boundary with Eurasia in the Timor and Papua New Guinea regions (Huston et al., 2012). As Australia has moved northwards it has come under the influence of the Earth's geoid high located beneath Indonesia, which is linked to the gravitational pull from accumulated subducted material at depth. There has been a consequent tilt of the continent towards the N, so that today Miocene sea cliffs on the northern margin of the Eucla Basin are more than $200 \mathrm{~m}$ above sea-level (Quigley et al., 2010).

Thick subcontinental lithosphere is difficult to melt, but can be mechanically weakened by stretching. The way in which sedimentary basins evolve through time, from rifting to thermal subsidence is strongly influenced by the thickness and structure of the underlying lithosphere. Heat takes longer to conduct through thick lithosphere, so that the thermal sag sedimentation phase following rifting is delayed and prolonged. Australia's intracontinental basins are widespread, and were filled over a prolonged time interval, as a consequence of the thick lithosphere. Many of these basins, which are typically $<5 \mathrm{~km}$ thick, comprise several successor basins that range in age from $850 \mathrm{Ma}$ to the Pliocene.

The crustal thickness on the Australian continent ranges from 25-60 km, with much of the crust between 38-42 km thick (Figure 11). The thickest crust occurs beneath the Paleozoic in the $E$ and in parts of central and northern Australia. Deep seismic reflection studies of the Australian Precambrian terranes support the concept of somewhat thickened Proterozoic crust compared to Archean crust, though there is no simple pattern of age progression (Aitken, 2010; Kennett et al., 2011). Drummond and Collins (1986) suggested that lower crustal mafic underplating was the main process responsible for this thickening. Such a mechanism would be consistent with the progressive loss of crustal reflectivity seen in reflection profiling across the regions with thickest crust; since interleaved mantle material reduces contrasts in physical properties. However, the same episodes of upper mantle melting do not appear to have underplated the Archean crust adjacent to the Proterozoic crust in the western part of the continent (Goncharov et al., 1998).

The crust is an integral component of the lithosphere and its thickness also controls the behaviour of the overall lithosphere to deformation (e.g., Behn et al., 2002). Thin crust results in deformation being localised into the mantle and so the width of any rift basin is controlled by the vertical geothermal gradient. Thick crust in contrast, allows stress accumulation in the crust to be greater than in the mantle, so rift basin width becomes dependent on both the vertical geothermal gradient and the rheology of the crust. Rifting tends to exploit former lines of weakness, but does not always succeed; Bass 
Strait represents a failed rift in the separation of Australia and Antarctica and this feature is linked to important sedimentary deposits with much of the known oil accumulations. The Centralian Superbasin is also located across the ancient sutures between northern and southern Australia.

Horizontal slices through the tomographic volume reveal additional complexity in Australia's deeper lithosphere. A zone of slower than average shear wavespeeds is imaged below the crust at $\mathrm{c}$. $75 \mathrm{~km}$ (Figure 12). This slow zone extends E-W across most of the continent and correlates broadly with the mobile belts that join the three cratonic elements of North Australia, South Australia and the West Australia (Huston et al., 2012). This zone also corresponds with the former extent of the Centralian Superbasin, which formed following rifting during the Neoproterozoic breakup of the supercontinent Rodinia at c. $825 \mathrm{Ma}$ (Li et al., 1999). These same regions have also experienced intense and punctuated contractional deformation that in places has exhumed mid crustal rocks to the surface. The slow wavespeeds at $75 \mathrm{~km}$ depth are difficult to explain, and the suitable combination of thermal or compositional structure remains a question of considerable scientific interest. For example, these slow wavespeed regions may have acted as, or continue today to act as, zones of lithospheric weakness. Such zones would favour the formation of sedimentary basins and mountain ranges and be the locus of seismicity.

Finer resolution of more subtle features with seismic tomography is possible where the data density is increased. Figure 9 shows the data network and reveals the much higher density of stations that have been deployed in recent years in the SE quarter of the continent. Tomographic imaging in this data-rich region (Figure 10) is able to resolve the deep boundary between the Neoproterozoic Delamarian and Paleozoic Lachlan orogens (of the Tasman Element) and the various blocks that comprise the latter. The Selwyn Block is thought to be an older crustal fragment of Neoproterozoic to Cambrian age that influenced the younger domains, some of which host the worldclass Victorian goldfields. These tomographic models provide constraints on the geometry of the blocks and the location of their boundaries. The slow wavespeed regions in Figure 9 likely correspond to the thermal effects of a mantle hot spot located beneath SE Australia; with the Pliocene and Pleistocene Newer Volcanic Group being the erupted products (Graeber et al., 2002).

Australia has not always been in the largely mid-plate position it finds today. Australia was part of the Earth's earlier (super)continents, with contributions to Vaalbra, Kenorland, Nuna, Rodinia and Pangea/ Gondwana (see Huston et al., 2012 and references therein). The evolution of these supercontinents has resulted in different lithospheric blocks first amalgamating and later rifting. As a consequence, the boundaries between these blocks can become pathways for fluids/ magmas to metasomatise the mantle. These boundary regions act as a source and pathway for fluids, many of which are implicated in the formation of giant mineral deposits (Hronsky and Groves, 2008). These deep boundaries can be imaged directly or inferred in various places by a number of techniques. Australia has a comprehensive series of deep seismic reflection profiles (Figure 9), which cross many of the continent's major geological provinces and boundaries (Chopping and Henson, 2009; Korsch and Kositcin, 2010a, b). Major structures are interpreted to transect the crust and in places offset the Moho. There are also distinctive differences in seismic characterthat is the amplitude and coherence of reflectors-between different crustal blocks in many deep seismic sections. Distinct boundaries between these different 'seismic provinces' are sometimes imaged, and some extend to the surface as known faults or sutures. In other places the boundaries themselves are indistinct and their presence is inferred by the changes in seismic character (Korsch and Kositcin, 2010a, b).

Thick lithosphere also impacts on resources such as diamonds. Diamonds are formed at high pressures $(>150 \mathrm{~km})$ and generally require a thick lithosphere and low geothermal gradient to form and be preserved. Australia is major diamond producer, especially from the Argyle deposit in NW Western Australia. The regional extent of this thick lithosphere and the longevity of the landscape should make Australia prospective for diamonds (O'Neill and Moresi, 2003).

A recent compilation of Australia's neotectonic features by Clark et al. (2011) has suggested that the distribution of seismic activity is dependent on whether the crust has been extended or not. In their definition, crust without extension includes cratons, platforms and fold belts, whereas extended crust includes intracontinental rifts of all ages and passive margins no younger than c. $25 \mathrm{Ma}$. The pattern found was that regions of extended crust tended to be more seismically active. The age of major rifting appears to be important in terms of neotectonic activity level in extended crustal domains so that Paleozoic intra-cratonic rifts and passive margins are less active than those rifted in the Mesozoic, with greater activity in NW than SE Australia (see Figure 6).

The Flinders Ranges in South Australia are accommodating around one third of the seismic strain across the whole the continent, but do not fit into the general pattern of age relations. These ranges are actively uplifting, with thrust faults placing Precambrian rocks onto Quaternary rocks in places (Quigley et al., 2010). This zone of weakness arises from the orientation of the current maximum stress direction perpendicular to basin controlling faults, coupled with the elevated heat flow in the region (Neumann et al., 2000).

\section{Conclusions}

The Australian lithosphere, and its constituent structures, is well mapped by a wide array of continental-scale geophysical datasets using many different techniques including potential fields, radiometry and seismological methods. Such results are of particular importance because extensive sedimentary basins and the draping of thick regolith across the landscape mean that exposed rocks or outcrop is limited.

The Moho, the major boundary in the upper lithosphere, is highly variable in its character and depth below the surface. Depths to Moho across the continent range from $25-60 \mathrm{~km}$, despite an average elevation of only c. $330 \mathrm{~m}$ above sea level. There are rapid variations in crustal thickness in central Australia that give rise to major E-W oriented gravity anomalies. The character of the transition from crust to mantle is highly variable with extended gradients accompanying the deepest Moho, probably associated with mafic underplating. There is no simple relationship between depth to Moho and crustal age, though many of the zones of thickest crust are in regions of Proterozoic outcrop.

More than two thirds of the Australian continent is underlain by lithosphere over $200 \mathrm{~km}$ thick, which is more than double the global average for lithospheric thickness. This thick lithosphere underlies the Precambrian zones of western and central Australia. It has controlled many features of Australian geology and geography; with a major influence on how the continent has responded to tectonic 
forces related to breakup and amalgamation. The contrasts in lithospheric thickness provide controls on topography and landscape, seismicity, the evolution of sedimentary basins evolution, heat flow and other resources.

\section{Acknowledgements}

Richard Blewett publishes with the permission of the CEO of the Geoscience Australia. The extensive set of national data bases held at Geoscience Australia (http://www.ga.gov.au), have been very valuable for the preparation of this article; much of these data are freely accessible. The programme of passive seismological studies has received considerable support from the Australian National University and, in recent years, from the Australian Research Council.

\section{References}

Aitken, A.R.A., 2010, Moho geometry gravity inversion experiment (MoGGIE): A refined model of the Australian Moho and its tectonic and isostatic implications: Earth Planetary Science Letters, v. 297, pp.7183.

Behn, M.D., Lin, J. and Zuber, M.T., 2002, A continuum mechanics model for normal faulting using a strain-rate softening rheology: implications for thermal and rheological controls on continental and oceanic rifting: Earth and Planetary Science Letters, v. 632, pp.1-16.

Blewett, R.S., Henson, P.A., Roy, I.G., Champion, D.C. and Cassidy, K.F., 2010, Scale-integrated architecture of a world-class gold mineral system: The Archaean eastern Yilgarn Craton, Western Australia: Precambrian Research, v. 183, pp. 230-250.

Braun, J., Dooley, J., Goleby, B., van der Hilst, R. and Klootwijk, C. (eds.), 1998, Structure and Evolution of the Australian Continent, American Geophysical Union, Geodynamic Series v. 25, 186 pp.

Chopping, R. and Henson, P.A. (eds.), 2009, 3D map and supporting geophysical studies in the North Queensland region: Geoscience Australia, Record 2009/29, 82 pp. http://www.ga.gov.au/image_cache/ GA15585.pdf

Christensen, N.I. and Mooney, W.D., 1995, Seismic Velocity Structure and Composition of the Continental Crust: A Global View: Journal of Geophysical Research, v. 100, pp. 9761-9788.

Clark, D., McPherson, A. and Collins, C.D.N., 2011, Australia's seismogenic neotectonic record: a case for heterogeneous intraplate deformation: Geoscience Australia, Record 2011/11, 95 pp.

Clitheroe, G., Gudmundsson, O. and Kennett, B.L.N., 2000, The crustal thickness of Australia: Journal of Geophysical Research, v. 105, pp. 13697-13713.

Collins, W.J. and Vernon, R.H., 1992, Palaeozoic arc growth, deformation and migration across the Lachlan Fold Belt, southeastern Australia: Tectonophysics, v. 214, pp. 381-400.

Debayle, E. and Kennett, B.L.N., 2000, The Australian continental upper mantle - structure and deformation inferred from surface waves: Journal of Geophysical Research, v. 105, pp. 25443-25540.

Debayle, E., Kennett, B. and Priestley, K., 2005, Global azimuthal seismic anisotropy: the unique plate-motion deformation of Australia: Nature, v. 433, pp. 509-512.

Direen, N.G. and Crawford, A J., 2003, The Tasman Line: where is it, what is it, and is it Australia's Rodinian breakup boundary? Australian Journal of Earth Sciences, v. 50, pp. 491-502.

DeMets, C., Gordon, R.G. and Argus, D.F., 2010, Geologically current plate motions: Geophysical Journal International, v. 181, 1-80.

Drummond, B.J. (ed.), 1991, The Australian Lithosphere: Geological Society of Australia, Special Publication v. 17, 208 pp.

Drummond, B.J. and Collins, C.D.N., 1986, Seismic evidence for underplating of the lower continental crust of Australia: Earth and Planetary Science Letters, v. 79, pp. 361-372.

Drummond, B.J., Barton, T.J., Korsch, R.J., Rawlinson, N., Yeates, A.N., Collins, C.D.N. and Brown, A.V., 2000, Evidence for crustal extension and inversion in eastern Tasmania, Australia, during the Neoproterozoic and Early Palaeozoic: Tectonophysics, v. 329, pp. 1-21.
Eaton, D.W., Darbyshire, P., Evans R.L., Grütter H., Jones, A.G. and Yuan, X., 2009, The elusive lithosphere-asthenosphere boundary (LAB) beneath cratons: Lithos, v. 109, pp. 1-22.

Farrington, R., Stegman, D., Moresi, L.N., Sandiford, M. and May, D., 2010, Interactions of 3D mantle flow and continental lithosphere near passive margins: Tectonophysics, v. 483, pp. 20-28, doi:10.1016/j.tecto.2009. 10.008

Fichtner, A., Kennett, B.L.N., Igel, H. and Bunge, H.-P., 2009, Full seismic waveform tomography for upper-mantle structure in the Australasian region using adjoint methods: Geophysical Journal International, v. 179, pp. 1703-1725.

Fichtner, A., Kennett, B.L.N., Igel, H. and Bunge, H.-P., 2010, Full seismic waveform tomography for radially anisotropic structure: New insights into the past and present states of the Australasian upper mantle: Earth and Planetary Science Letters, v. 290, pp. 270-280.

Finlayson, D.M., 2010, A Chronicle of Deep Seismic Profiling across the Australian Continent and its Margins, 1946-2006: D.M. Finlayson, Canberra, 255 pp. (available from: doug.finlayson@ netspeed.com.au).

Fishwick, S., Kennett, B.L.N. and Reading, A.M., 2005, Contrasts in lithospheric structure within the Australian Craton: Earth and Planetary Science Letters, v. 231, pp. 163-176.

Fishwick, S., Heintz, M., Kennett, B.L.N., Reading, A.M. and Yoshizawa, K., 2008, Steps in lithospheric thickness within eastern Australia, evidence from surface wave tomography: Tectonics, v. 27, TC0049, doi:10.129/ 2007 TC002116.

Fouch, M.J. and Rondenay, S., 2006, Seismic anisotropy beneath stable continental interiors: Physics of the Earth and Planetary Interiors, v. 158 , pp. 292-320, doi:10.1016/j.pepi.2006.03.024

Frogtech, 2005. OZ SEEBASE ${ }^{\mathrm{TM}}$ Study 2005: Public Domain Report to Shell Development Australia by FrOG Tech Pty Ltd.

Goes, S., Simons, F.J. and Yoshizawa, K., 2005, Seismic constraints on the temperature of the Australian uppermost mantle: Earth and Planetary Science Letters, v. 236, pp. 227-237, doi:10.1016/j.eps1.2005.05.001

Goleby, B.R., Shaw, R.S., Wright, C., Kennett, B.L.N. and Lambeck, K., 1989, Geophysical evidence for 'thick-skinned' crustal deformation in central Australia: Nature, v. 337, pp. 325-330.

Goleby, B.R., Korsch, R.J., Fomin, T., Bell, B., Nicoll, M.G., Drummond, B.J. and Owen, A.J., 2002, Preliminary 3-D geological model of the Kalgoorlie region, Yilgarn Craton, Western Australia, based on deep seismic-reflection and potential-field data: Australian Journal of Earth Sciences, v. 49, pp. 917-933.

Goncharov, A.G., Lizinsky, M.D., Collins, C.D.N., Kalnin, K.A., Fomin, T.N., Drummond, B.J., Goleby, B.R.G. and Platonenkova, L.N., 1998, IntraCrustal "Seismic Isostasy" in the Baltic Shield and Australian Precambrian Cratons from Deep Seismic Profiles and the Kola Superdeep Bore Hole Data, in Braun, J. et al. (eds), Structure and Evolution of the Australian Continent, Geodynamics Series, v. 26, pp. 119-138.

Graeber, F.M., Houseman, G.A. and Greenhalgh, S.A., 2002, Regional teleseismic tomography of the western Lachlan Orogen and the Newer Volcanic Province, southeast Australia: Geophysical Journal International, v. 149 , pp. 249-266.

Gudmundsson, O., Kennett, B.L.N. and Goody, A., 1994, Broadband observations of upper mantle seismic phases in northern Australia and the attenuation structure in the upper mantle: Physics of the Earth and Planetary Interiors, v. 84, pp. 207-236.

Heinson, G.S., Direen, N. and Gill, R., 2006, Magnetotelluric evidence for a deep-crustal mineralising system beneath the giant Olympic Dam IronOxide Copper Gold deposit, southern Australia: Geology, v. 34, pp. 573 576.

Heintz, M. and Kennett, B.L.N., 2005, Continental scale shear-wave splitting analysis: Investigation of seismic anisotropy underneath the Australian continent: Earth Planetary Science Letters, v. 236, pp. 106-119.

Hronsky, J.M.A. and Groves, D.I., 2008, Science of targeting: definition, strategies, targeting and performance measurement: Australian Journal of Earth Sciences, v. 55, pp. 3-12.

Huston D.L., Blewett, R.S. and Champion, D.C., 2012, The evolution of the Australian continent: Episodes, v. 35 (this volume), pp. 23-44.

Hillis, R.R. and Müller, R.D. (eds.), 2003, Evolution and dynamics of the Australian Plate: Geological Society of Australia, Special Publication v. 22 and Geological Society of America, Special Paper v. 372, 432 pp.

James, D.E., Fouch, M.F., VanDecar, J.C., van der Lee, S. and the Kaapvaal Seismic Group, 2001, Tectospheric structure beneath southern Africa, 
Geophysical Research. Letters, v. 28, pp. 2485-2488.

Jones, T.D., Kirkby, A.L., Gerner, E.J. and Weber, R.D., 2011, Heat flow determinations for the Australian Continent: Release 2. Geoscience Australia, Record 2011/28, 24 pp.

Kennett, B.L.N. and Abdulah, A., 2011, Seismic wave attenuation beneath the Australasian region: Australian Journal of Earth Sciences, v. 58, pp. 285-295.

Kennett, B.L.N. and Furumura T., 2008, Stochastic waveguide in the Lithosphere: Indonesian subduction zone to Australian Craton: Geophysical Journal International, v. 172, pp. 363-382.

Kennett, B.L.N., Salmon, M., Saygin, E. and AusMoho Working Group, 2011, AusMoho: the variation of Moho depth in Australia: Geophysical Journal International, v. 187, pp. 946-958.

Kirkby, A.L. and Gerner, E.J., 2010, Heat flow interpretations for the Australian continent: Release 1. Geoscience Australia, Record 2010/41, 28 pp.

Korsch, R.J. and Kositcin, N. (eds), 2010a, GOMA (Gawler Craton-Officer Basin-Musgrave Province-Amadeus Basin) Seismic and MT Workshop 2010: Geoscience Australia, Record 2010/39, 162 pp.

Korsch, R.J. and Kositcin, N. (eds), 2010b, South Australian Seismic and MT Workshop 2010: Geoscience Australia, Record 2010/10, 124 pp.

Lambeck, K., Burgess, G. and Shaw, R.D., 1988, Teleseismic travel-time anomalies and deep crustral structure in central Australia: Geophysical Journal of the Royal Astronomical Society, v. 94, pp. 105-124.

Lee, C-T.A., Luffi, P. and Chin, E.J., 2011, Building and Destroying Continental Mantle: Annual Review of Earth and Planetary Sciences, v. 39, pp. $59-90$.

Li, Z.X., Li, X.H., Kinny, P.D. and Wang, J., 1999, The breakup of Rodinia: did it start with a mantle plume beneath South China? Earth and Planetary Science Letters, v. 173, pp. 171-181.

Minty, B., Franklin, R., Milligan, P., Richardson, M. and Wilford, J., 2009, The Radiometric Map of Australia: Exploration Geophysics, v. 40, pp. 325-333.

Müller, R.D., Roest, W.R., Royer, J.-Y., Gahagan, L.M. and Sclater, J.G., 1997, A digital age map of the ocean floor: SIO Reference Series 93-30, Scripps Institution of Oceanography.

Neumann, N., Sandiford, M. and Foden, J., 2000, Regional geochemistry and continental heat flow: implications for the origin of the South Australian heat flow anomaly: Earth Planetary Science Letters, v. 183, $107-120$.

O'Neill, C. and Moresi, L., 2003, How long can diamonds remain stable in the continental lithosphere? Earth and Planetary Science Letters, v. 213, pp. $43-52$.

Pillans, B., 2008, Regolith through time, in Scott, K.M. and C.F. Pain (eds), Regolith Science: CSIRO Publishing, Australia, pp. 7-30.

Quigley, M.C., Clark, D. and Sandiford, M. 2010, Tectonic geomorphology of Australia: Geological Society of London, Special Publication v. 346, pp. 243-265.

Rawlinson, N., Tkalèiæ, H. and Reading, A.M., 2010, Structure of the Tasmanian lithosphere from 3D seismic tomography: Australian Journal

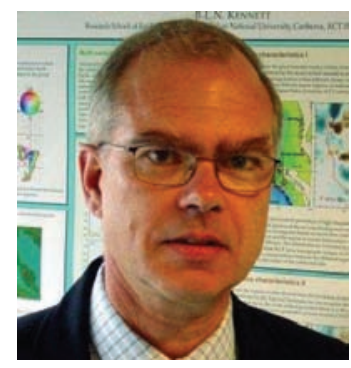

Brian Kennett is currently Professor of Seismology at the Australian National University. He received his $P h D$ in Theoretical Seismology from the University of Cambridge in 1973. He moved to Australia in 1984, and was President of the International Association of Seismology and Physics of the Earths Interior from 1999-2003. His research has covered a very wide range of topics in seismology, from reflection seismology to studies of the deep Earth and from theoretical to observational studies. He has received recognition through many medals and awards. of Earth Sciences, v. 57, pp. 381-394.

Rawlinson, N., Kennett, B.L.N., Vanacore, E., Glen, R.A. and Fishwick, S. 2011, The structure of the upper mantle beneath the Delamerian and Lachlan orogens from simultaneous inversion of multiple teleseismic datasets: Gondwana Research, v. 19, pp. 788-799.

Reading, A.M., Kennett, B.L.N. and Goleby, B.R., 2007, New constraints on the seismic structure of West Australia: Evidence for terrane stabilization prior to the assembly of an ancient continent? Geology, v. 35, pp. 379382. doi: 10.1130/G23341A.1.

Saygin, E. and Kennett, B.L.N., 2010, Ambient noise tomography for the Australian Continent: Tectonophysics, v. 481, pp. 116-125, doi:10.106/ j.tecto.2008.11.013

Selway, K., Heinson, G. and Hand, M. 2006, Electrical evidence of continental accretion: steeply-dipping crustal-scale conductivity contrast: Geophysical Research Letters, v. 33, L06305, 4 pp, doi:10.1029/ 2005GL025328.

Shibutani, T., Sambridge, M. and Kennett, B., 1996, Genetic algorithm inversion for receiver functions with application to crust and uppermost mantle structure beneath eastern Australia: Geophysical Research Letters, v 23, pp. 1829-1832.

Simons, F.J., van der Hilst, R.D., Montagner, J.P. and Zielhuis, A., 2002, Multimode Rayleigh wave inversion for shear wave speed heterogeneity and azimuthal anisotropy of the Australian upper mantle: Geophysical Journal International, v. 151, pp. 738-754, doi:10.1046/j.1365246X.2002.01787.x.

Stüwe, K., 1991, Flexural constraints on the denudation of asymmetric mountain belts: Journal of Geophysical Research, v. 96, pp. 10401-10408.

Tregoning, P., 2003, Is the Australian Plate deforming? A space geodetic perspective: Geological Society of Australia, Special Publication, v. 22, pp. $41-48$

Tong, C., Gudmundsson, O. and Kennett, B.L.N., 1994, Shear wave splitting in refracted waves returned from the upper-mantle transition zone beneath Northern Australia: Journal of Geophysical Research, v. 99, pp. 1578315797.

van der Hilst, R., Kennett, B.L.N., Christie, D. and Grant, J., 1994, Project SKIPPY explores the lithosphere and mantle beneath Australia: EOS Transactions AGU, v. 75, p. 177.

van Ufford, A.Q. and Cloos M., 2005, Cenozoic tectonics of New Guinea: AAPG, Bulletin 89, pp. 119-140.

Weber, R.D., Kirkby, A.L. and Gerner, E.J., 2011, Heat flow determinations for the Australian continent: Release 3: Geoscience Australia, Record 2011/30, 60 pp.

Wilford, J.R., 2011, A weathering intensity index for the Australian continent using airborne gamma-ray spectrometry and digital terrain analysis: Geoderma, in press, doi: 10.1016/j.geoderma.2010.12.022.

Yoshizawa, K. and Kennett, B.L.N., 2004, Multi-mode surface wave tomography for the Australian region using a 3-stage approach incorporating finite frequency effects: Journal of Geophysical Research, v. 109, B02310, doi: 10.129/2002JB002254.

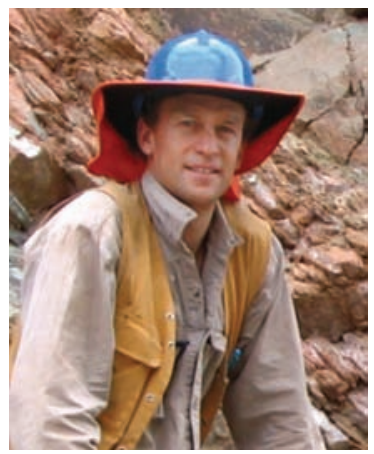

Richard Blewett graduated from Swansea University (Wales) in 1995. He completed a PhD in structural geology from Leicester University in the UK. During this time he did fieldwork in the Appalachians, Caledonides and Himalayas. Richard joined Geoscience Australia in 1990 and has worked on the tectonics and mineral systems of NE Queensland, North Pilbara, Sultanate of Oman, Eastern Goldfields (WA), GawlerCurnamona, central Australia and Capricorn Orogen (WA). He is interested in the management of science and research and has an MBA from Deakin University (2001). 